ROCZNIKI HUMANISTYCZNE

Volume 67, issue $4-2019$

SELECTED PAPERS IN ENGLISH

DOI: http://dx.doi.org/10.18290/rh.2019.67.4-7en

\title{
DOROTA KUDELSKA
}

\section{MALCZEWSKI AND VIENNA: NEW FACTS*}

Since my monograph work on the author of Introdukcje-Dukt pisma i pędzla. Biografia intelektualna Jacka Malczewskiegoand its significantly changed and supplemented version, Malczewski. Obrazy i Stowa, while gathering the artist's correspondence and other documents, I have come across new material on his relationships with the artistic circles of Vienna. This has offered me a broader research perspective on the Viennese artistic fraternity. Also, some new studies have been published discussing the position and activities of Karol Lanckoroński. ${ }^{1}$ When it comes to the new material, of key importance is the artist's correspondence with Juliusz Twardowski ${ }^{2}$ concerning Malczewski's

Dr Dorota KudELSKA, associate professor-Department of the History of Early Christian Art and Antique Tradition, John Paul II Catholic University of Lublin, Al. Racławickie 14, 20-950 Lublin; email: kudelska@kul.pl

The Polish version of the article was published in Roczniki Humanistyczne vol. 65, issue 4 (2017).

* This article was delivered under Grant No. 2011/01/B/HS2/05889: The Collection and Scientific Study of Jacek Malczewski's Archives.

${ }^{1}$ Dorota KudELSKA, Dukt pisma i pędzla. Biografia intelektualna Jacka Malczewskiego (Lublin: Wydawnictwo KUL, 2008); EADEM, Malczewski. Obrazy i słowa (Warszawa: Wydawnictwo W.A.B., 2012); Lanckoroniana, vol. 1-4, red. serii B. Dybaś (Wiedeń: Stacja Naukowa PAN, 2015).

${ }^{2}$ Seven Letters of Jacek Malczewski to Juliusz Twardowski, Kazimierz Wielki University in Bydgoszcz, Juliusz Twardowski Archive (1900-1944), man. 26, non-numbered sheets.

Juliusz Twardowski (1874-1945), graduate of the Collegium Teresianum, lawyer, long-time employee of the Austrian administration (Treasury Prosecutor's Office, Ministry of Trade, Ministry of Public Works: 1907-1910, Presidium of the Council of Ministers, Galicia Department: 1910-1917); he formally held the office of a minister without portfolio in the government of Ernst Seidler (19171918, after the abdication of the last of the Habsburgs). In the period between the wars, he worked for the Polish government. Waldemar Łazuga, Kalkulować... Polacy na szczytach c. k. monarchii (Poznań: Wydawnictwo Zysk i S-ka, 2013), s. 341, 377, 379, 386, 388-389. 
studio in Prater, spanning the years 1900-1912 and the early years of World War I as well as previously unknown photographic records of the XXXIX. Ausstellung der Vereinigung Bildender Künstler Österreichs Secession, focus ing on a showcase of Malczewski's works and Procession to Wawel by Wacław Szymanowski. ${ }^{3}$

Because I already discussed Malczewski's visits to Vienna and his contacts with Viennese institutions in the publications mentioned above, I will only refer to them cursorily as a starting point for new findings. The contacts date back to July 1873 with Malczewski's trip to the Vienna World's Fair. The journey was organized by Piotr Hubal Dobrzański, mentor of the soon-to-be artist, shortly after Malczewski's resignation from education at Saint Hyacinth Gymnasium and moving to the Kraków's School of Fine Arts. Julian Malczewski joined them soon. We provided an accurate account of the trip in his letters to his wife. From the huge exhibition scattered across the city, they chose art, especially painting sections, including Austrian and French works (about 2000 items), "products of Japan and Brazil, a few from Italy." The contemporary press and the Officieller Kunst-Catalog give an idea about the size and volume of the fairs. ${ }^{5}$ The Japanese section enjoyed such a great popularity that it had its extra catalogue covering painting on fabric, wood engraving, porcelain and fans, as well as castings as everyday items and sculptures. The exhibition as a whole made a great impression on the Polish visitors (including Maksymilian Gierymski and Leon Wyczółkowski but also Gustav Klimt). ${ }^{6}$ Malczewski’s reception of

\footnotetext{
${ }^{3}$ XXXIX. Ausstellung der Vereinigung Bildender Künstler Österreichs Secession, Wien, November 1911-Jänner 1912, Vereinigung bildender Künstler Österreichs -Wiener Secession, Wien 1911.

${ }^{4}$ KudELSKA, Dukt pisma i pędzla, 524.

${ }^{5}$ Officieller Kunst-Catalog Welt Ausstellung 1873 in Wien (Wien: Verl. der General-Direction 1873); see also Kunst und Kunstgewerbe auf der Wiener Weltausstellung 1873. Herausgegeben von Carl Lützow (Leipzig: Vorlag von E.A. Seemann, 1875).

${ }^{6}$ Maksymilian i Aleksander Gierymscy. Listy $i$ notatki, zebrał, ułożył i wstępem opatrzył Juliusz Starzyński, teksty do druku i komentarze opracowała Halina Stępień (Wrocław-Warszawa-Kraków, 1973), s. 96, 128, 135,137; zob. też Herbert FuX, Japan auf der Weltausstellung in Wien 1873 (Wien: Österreichisches Museum für angewandte Kunst, 1973). Extremely interesting reflections on the relationship between modern Viennese art and Japanese art (and, more broadly, on the varieties of Asian art) as from 1870 in Gustav Klimt. In search of the "Total Artwork," ed. Jane Kallir, co-ed. Alfred WeIDINGER, [Exhib. cat. Hangaram Art Museum, Seoul Arts Center, South Korea, February 1-May 15, 2009] (Munich, Berlin, London, New York: Prestel, 2009), here: Alfred WeIDINGER, Women and Nature in the work of Gustav Klimt, 30-41.
} 
art at that time was probably still immature, but he was very content with the trip, as we learn from his letters.

During his two-week visit to Weltausstellung, the future artist would pass by and probably visit the landmark edifice of the Künstlerhaus. He would often wander with his companions through Karlsplatz; they lived nearby, in Salezianergasse; they crossed the square on their way to the opera house, Hofburg and the Kunsthistorisches Museum, and also to the old town.

The social rank and type of art showcased in Vienna were undoubtedly significant for Julian Malczewski, who was sensitive to the social status of an artist as an exceptional but dependable person (not disturbing the moral order). For him Jan Matejko's position and activity set the standard of painter's prestige. Undoubtedly, he took his son to the Künstlerhaus where the author of Rejtan exhibited his works, and even Emperor Franz Joseph purchased some of them. ${ }^{7}$ Finally, the Gesellschaft Bildender Künstler Österreichs saw the exhibitions of many well-known, old-generation Polish painters from the Munich group as well as those who had left Poland after 1863 (including Józef Brandt, Roman Kochanowski, and Maksymilian Gierymski ${ }^{8}$ ). The Künstlerhaus was certainly in the Malczewskis' focal point.

Little is known about Malczewski's contacts with the Vienna circles in the 1880s. Certainly he visited the city during his trips abroad (in 1880 with Marceli Czartoryski en route to Venice; in 1884 with Karol Lanckoroński to Asia Minor and in 1890 also with Lanckoroński to Italy). In 1895, as part of a presentation of Count Ignacy Milewski’s collection, Malczewski’s paintings were displayed in the most important Viennese exhibition house of European significance, the Künstlerhaus. ${ }^{9}$ The exhibition was very fashionable and well received by the

\footnotetext{
7 "Führer durch die Gemäldegalerie Neue Maister, Bd. III: Gemälde moderner Maister. Aquarelle und Handszeichnungen, A. Schaeffer, Vorbemerkung," in Selbstverlage der kunsthistorischen Sammlungen des Allerhöchsten Kaiserhauses (Wien: Adolf Holzhausen, 1907), 86-87, No. 176: Jan MATEJKO, Der Reichstag zu Warschau Jahre 1773.

${ }^{8}$ Dorota KUDELSKA, "Polnischen Malern aus München im Gemäldeausstellungen im Wiener Künstlerhaus.” In Das Exotische Europa, Heimatsvisionen auf den Gemälden der polnischen Künstler in München im XIX. Jh, ed. Eliza Ptaszyńska (Suwałki: Muzeum Okręgowe w Suwałkach, 2015), 6977 (also Polish version available).

${ }^{9}$ Katalog Ausstellung im Künstlerhause. 22. Dezember 1895, [foreword] Dr Cyprianus Bodenstein, I und II. Gräflich I. Milewski'sche Sammlung [s. 3-9], Gesellschaft bildender Künstler Österreichs, Wien, 1895.
} 
press, but Malczewski's work went unnoticed, unlike those of Aleksander Gierymski's. ${ }^{10}$ Already in the early 1890s, Malczewski's colleagues (Maurycy Gottlieb, Kazimierz Pochwalski, Wojciech Kossak, Olga Boznańska) start exhibiting individually in the Künstlerhaus and receive awards, which resonated in the Kraków press. Undoubtedly, it was vigorously debated across the artistic community, and Malczewski was an ambitious artist. Therefore, it is somewhat puzzling that his letters, documents and memories about the artist lack information and mentions about his approach to the Künstlerhaus. Of course, it can be assumed that, as a mature artist, he did not take any personal effort to exhibit in such a prestigious location, and that he did not care about it. However, this is not a satisfactory answer, yet no other can be provided at this point. Malczewski also appeared in Vienna at a collective showcase of Polish art in $1915 .{ }^{11}$ Perhaps some more light can be cast on the matter after a further search query in the extensive archives of the Künstlerhaus, which had had no competition in Vienna until the late 1890s. ${ }^{12}$ The rebellion against the monopoly of the Künstlerhaus resulted in the establishment of the Vienna Secession movement in 1897. Its first exhibition lasted from March to May 1898, and some time later appeared in the Künstlerbund Hagen in Zedlitzhalle (1900). Soon, the Miethke Gallery (from 1906, i.e. the appointment of Carl Moll as director) and the Kunstsalon Pisko (1906) also began to play an important role. Apart from the Secession, none of these sites never showed Malczewski's works, although other Polish artists exhibited there. And things had looked so promising so far... Malczewski's closer ties with the Vienna artistic community begin even before the first exhibition of the Secession, i.e. as early as in January 1898. A reproduction

\footnotetext{
${ }^{10}$ Aleksander Gierymski made his debut in Vienna at the World's Fairs in 1873. He lived in Vienna for almost a year undergoing a neurological therapy (1884); he visited the Künstlerhaus regularly (where he also exhibited in 1884, 1890, 1894, 1895, 1896). Ludvig Hevesi noted and was very positive about Milewski's exhibition. He remembered his works well, and years later he covered them in his study on Polish painting in Austria. Ludvig HevesI, Österreichische Kunst im Neunzehnten Jahrhundert (Leipzig: Seemann Leipzig, 1903), 313.

${ }^{11}$ Katalog der polnischen Künstlerausstellung, mit einem Vortwort von Prof.dr. J. v. Bołoz Antoniewicz (Wien-Künstlerhaus [11.April bis 10.Mai], 1915); about Malczewski in "Moderne Abteilung," items 82-89.

${ }^{12}$ Wladimir Aichelburg, "Die Künstlergenossenschaft und ihre Rivalen Secession und Hagenbund," in IDEM, Das Wiener Künstlerhaus 1861-2001, Band 1 (Wien: Österreichischer Kunst- und Kulturverlag, 2003).
} 
of Malczewski's painting was printed in the top-rated, official group's magazine, Ver Sacrum. It accompanied a programme statement by Ludvig Hevesi in the first issue of the magazine. That leading Viennese critic, one of the group's ideologist, discussed the works of contemporary artists, including Koloman Moser and Gustav Klimt. He wrote about the objectives and challenges of the new art, its new forms and symbols stirring audience's emotions and intellect. He did not interpret Malczewski's Polnischer Pegasus, but it was used as a conclusion to that important text. ${ }^{13}$ In March Malczewski appears in the first catalogue (along with nine other Poles) among the founders-members of the movement. ${ }^{14} \mathrm{He}$ does not exhibit but observes the famous pavilion. He wrote Hevesi to congratulate on the new magazine; certainly, he read Życie edited by Ludwik Szczepański and regularly reporting on "the modern from Vienna." As a member of the Society of Polish Artists "Sztuka," he took part in its meetings where, according to reports, the Viennese exhibitions of Poles were discussed. ${ }^{15}$

Around 1900, Malczewski's family situation ${ }^{16}$ and the events unfolding in the artistic community probably led him to look for a studio (including an apartment) in Vienna. Until now, this has been confirmed only by a reminder to pay the rent for his premises in Prater dated 28 August 1912. ${ }^{17}$ The document proved that, contrary to the opinions naively mythicizing the artist's patriotism, Malczewski was capable of working abroad. However, the new archives mentioned at the beginning of the article, i.e. Juliusz Twardowski's letters, contribute new information, although they do not cover the entire course of events. It is not known how the correspondents established contact, perhaps it was through Lanckoroński (?), who is also mentioned in the letters when talking about the studio.

\footnotetext{
${ }^{13}$ Ludvig Hevesi, "Vereinigung Bildender Künstler Österreichs," Ver Sacrum 1 (1898), H. 1: 811, fig. 9; a detail analysis of the article and Malczewski's correspondence with the Wiener Secession: KudelsKa, Dukt pisma i pędzla, 527-531.

${ }^{14}$ Roman TABORSKI, Wśród wiedeńskich poloników (Kraków: Wydawnictwo Literackie, 1974), 188-189.

${ }^{15}$ Dorota KudELSKA, "Wiedeńskie kontakty 'Sztuki'—z zapisów w Księdze Protokołów Towarzystwa Artystów Polskich,” Annales UMCS 35, no 1 (2017), sec. FF, 2016: 124-139.

${ }^{16}$ The artist spent the Christmas of 1899 alone for the first time. It was the result of a prolonged marital crisis; in the following years, the situation even deteriorated. KUDELSKA, Dukt pisma i pędzla, 189-190.

${ }^{17}$ Ibidem, 529-532.
} 
In the first letter (dated 23 January 1900), probably mailed from Kraków, the artist is pleased with his legal advisor's assurance that the studio in Prater may be at his disposal in the future (although he does not specify when),

I feel that this is only owing to his [Twardowski's - D.K.] efforts...So, how should I respond to his goodness? Is my gratitude going to be sufficient? ${ }^{18}$

Malczewski strives to occupy a studio in Prater, on the premises vacated by the 1873 World's Fairs, in the former imperial hunting grounds. Later, the area around the largest exhibition pavilion (the so-called Rotunda that burned down in 1937) became a popular destination for Viennese strollers. Because of the numerous restaurants and cheap entertainment, this part of the district was called Wurstprater. But high art also had its place in the huge park, namely the Kunsthof. This part of the post-fair grounds housed art pavilions under the governmental administration (opened in 1875 by Franz Joseph in person). The Kunsthof studies were rented by interior designers, sculptors, amateur and qualified painters and artists and female painters from private art schools. ${ }^{19}$

In the spring of 1902, the 14th Secession exhibition, Beethoven Ausstellung, saw the presentation of Beethoven's Frieze by Klimt, which is relevant for our discussion for two reasons. First of all, in January 1903, outraged by the new forms, Malczewski wrote a letter to Lanckoroński to state his views and predictions of the development of art. ${ }^{20}$ Second of all, the count was known for his reluctance to the modern, as demonstrated in his opinions and actions, so he shared Malczewski's resentment. That had a bearing in practice because Lanckoroński was a member of governmental art committees and advised public

\footnotetext{
${ }^{18}$ J. Malczewski to Juliusz Twardowski, Manuscript Department of Kazimierz Wielki University, Juliusz Twardowski's Archives (1900-1944), man. 26, non-numbered sheets., [letter 1] dated 23.01.1900.

${ }^{19}$ Emperor Joseph II opened these areas to the Viennese in 1766; before 1873 they were not well connected with the city centre. Arkadien und angenehme Feinde. Die Bildhaueratelier im Prater, Hrsg. Werner Würtinger, ed. Rosa Hausleithner (Wien: Revolver Publishing, 2011).

${ }^{20}$ The correspondence was directly related to the publication and distribution of the Lanckoroński's brochure, Nieco o nowych robotach w katedrze na Wawelu (Vienna, December 1902/January 1903), see KuDELSKa, Dukt pędzla i pisma, 579-597.
} 
bodies on the purchase of works of art. ${ }^{21}$ His dislike of Klimt had some further negative consequences for Malczewski.

Despite the rejection of the direction of aesthetic transformation of the Viennese association, Malczewski took part in the 15th Secession exhibition featuring numerous works by artists from the Society of Polish Artists "Sztuka." $22 \mathrm{He}$ had been on a winning streak at the time. It began in the spring of 1903 when his friends and supporters, led by Jan Bołoz Antoniewicz, organized his first solo exhibition in Lviv (supported by Jerzy Mycielski, Konstanty M. Górski, and K. Lanckoroński). The exhibition was very popular, and the organizers planned to export it abroad. The plan was made public in the press. ${ }^{23}$ Perhaps Malczewski personally submitted the proposal to the Wiener Secession. How ever, in August 1903, Felician Myrbach (the head of the association) refused him. Although Malczewski's terms, especially concerning the timing, are not known, to justify the refusal by the necessity of "repairs in the exhibition rooms" sounds like an obvious diplomatic manoeuvre for anyone who knows the small exhibition building which was new at the time. After all, no later date was proposed. A month after Myrbach's letter, Malczewski learned that Lanckoronski had offered to pay for transport and preparation of the exhibition. ${ }^{24}$ In view of count's poor relations with the Secession discussed above, it can be assumed that the sponsor did not help Malczewski get closed to his goal. However, Malczewski soon undertook an important challenge. He staged the exhibition of

\footnotetext{
${ }^{21}$ Karol Lanckoroński was a member of several teams of museum curators-k.k. Österreichisches Handelsmuseum and k.k. Österreichisches Museum für Kunst und Industrie; worked in the Ministry of Religious Affairs and Education and for the Kunstkommission (from 1900) and Kunstrat (from 1902). He also indebted his position in the art world to his acquaintance with Minister Wilhelm von Hartel, after Katrin JILEK, "Karol Lanckoroński i jego spuścizna rękopiśmienna w zbiorach Austriackiej Biblioteki Narodowej," in Karol Lanckoroński i jego czasy. Varia, (Lanckoroniana, vol. 1) (Vienna: Österreichische Nationalbibliothe, 2015), 14; Joanna WINIEWICZ-WoLSKA, "Karol Lanckoroński- 'ostatni humanista wśród europejskiej arystokracji'," http://www.viennapan.org/index.Iphp/ badania/lanckoronski/o-karolu-lanckoronskim/biografia [last access: 15.04.2016].

${ }^{22}$ XV. Ausstellung der Vereinigung Bildender Künstler Österreichs Secession, Wien, Nov.-Dez. 1902, item 104.

${ }^{23}$ [Column: Kronika Powszechna], "Nauka i literatura we Lwowie," Tygodnik Ilustrowany 18 (1903), (first six months.): 357-358.

${ }^{24}$ See Mieczysław PASzKIEwICZ (comp.), "Listy Jacka Malczewskiego do Karola Lanckorońskiego,” Roczniki Historii Sztuki 18 (1990): 246; KudELSKA, Dukt pisma i pędzla, 535-538.
} 
the Sztuka Society of Polish Artists at the Louisiana Purchase Exposition in St. Louis, Missouri, and corresponded with the Secession to discuss the matter. ${ }^{25}$

From the end of 1904 to mid-1906, Wojciech Kossak expressed his concern about Malczewski in his letters to some mutual friends. He was trying to find customers for him and encouraged him to rent a study in Prater, Vienna (he used one himself, and even admitted that it was thanks to Lanckoroński's aid); apparently, he did not know about Malczewski's prior attempts to do the same. ${ }^{26}$ In the years 1905-1906, many close friends of the author of Introdukcja realized that he had been going through a serious and life-threatening health crises (the effects of venereal disease and concealed depression). In his letter to Lanckoroński, Kossak mentions that in November 1904 Malczewski worked in Vienna on Portrait of Wilhelm August von Hartel, which is missing today. ${ }^{27}$ Knowing the artist's habits, there is a high degree of probability that he had certainly provided for the right place to work in. After all, wherever he went-even on holidays, he expected to paint and tried to make sure that he would have somewhere to do it.

Any further known correspondence with Twardowski (maintained already for some time, as the context may suggest) comes from January 1911. Interestingly, Polish artists had had two earlier large exhibitions as the Sztuka Society of

\footnotetext{
${ }^{25}$ The first version of the exhibition was prepared by the so-called decorators, i.e. artists who soon resigned from membership in the Secession to form the Klimt Group. They advocated decorative, two-dimensional, and abstract painting. The exhibition intended for St. Louis did not include the works by colleagues following traditional art, and the first group of exhibiting artists were only Aus trians. The Ministry of Religions and Education rejected the proposal. A separate room for the Sztuka society was not only organized under the Secession (in financial terms). It was in fact its representation at St. Louis because, as it may be inferred, Vienna made the ultimate selection of works for the exhibition, and the members of the Sztuka Society of Polish Artists were mostly members of the Wiener Secession. Therefore, Anna Brzyski's opinion that the Secession lost its influence and was not represented at this exhibition is debatable. See Anna BRZYSKI, "Vienna Secession, Hagenbund, Sztuka, Mánes: Competition and Strategic Collaboration among Central European Art Groups," Centropa 11, issue 1 (2011): 4-16 (13). See also J. Malczewski do Wiener Secession, Wien, Archiv der Secession, 25.4.6. / 6052, in KudELSKA, Dukt pisma i pędzla, 536; Gustav Klimt Dokumentation, ed. by Christian M. Nebehay (Wien: Christian M. Nebehay, 1969); Susanna PARTsCH, Klimt. Życie i twórczość, transl. by Ana Kozak (Warszawa: Arkady, 1998) (1 ${ }^{\text {st }}$ ed. in German, 1993), 86-107.

26 "W. Kossak do żony,” in W. Kossak, Listy do żony i przyjaciół (1883-1942), selection, compilation, introduction, footnotes and indexes by Kazimierz Olszański, vol. 1 (Kraków: Wydawnictwo Literackie, 1985), item 682.

27 "W. Kossak do M. Eysmondowej,” in Listy, item. 608 and "W. Kossak do żony,” item 640.
} 
Polish Artists: in 1906 at the Wiener Secession and twice in Hagenbund in $1908 .{ }^{28}$ Malczewski's works were not shown at any of them, nor did he display his paintings individually. His absence from the Art group in Vienna in 1906 can be explained both by the artist's very poor health condition and the fact that he was at variance with the group. Yet, his 1908 absence cannot be explained, at least for the time being, in any way other but with some internal discord within Kraków's artistic circles. ${ }^{29}$

Reconstruction of further course of events in Vienna, also related to Malczewski's studio, is challenging as he suspended his correspondence with Twardowski for 11 years. In his 19 January 1911 letter, the artist wrote,

I hasten to express my gratitude for your kindness and grace. I owe you my studio in Prater. I have already started paying the rent although I am going to move in no earlier than in spring. I think I will be in Vienna soon, so I will be able to thank you in person... ${ }^{30}$

It is not known when the painter began to use his rented studio. Perhaps, much earlier, i.e. in December 1911? Was it directly related to his preparations for a major show at the end of December 1911 and in January 1912 at the Wiener Secession ? $^{31}$ The exhibition covered the largest number of Malczewski's works shown outside Poland (40). It was organized on the initiative of Wackaw Szymanowski (also presenting his sculptures, including Procession to Wawel) and Julian Makarewicz, who paid for the shipment of artist's works to Vienna. ${ }^{32}$

\footnotetext{
${ }^{28}$ On Polish artists in Hagenbund, see "An Undervalued Place of often Unwelcome Painters. Polish Art in the Hagenbund," in A European Network of Modernism (1900 to 1938), trans. by Russel Stockman, Jeremy Geins [German into English], ed. Agnes Husslein-Arco, Matthias Boekl, Harald Krejci (Vienna: Belvedere, 2014), 307-317.

${ }^{29}$ In Vienna, until then, Hagenbund had presented art that was acceptable for Malczewski, but, as a gallery, it became too controversial after February 1911. The famous Neukunstgruppe exhibition was put on then organized by Schiele and Kokoschka. The artist probably did not accept that "expressionist scandal," as he did not Beethoven's Frieze before.

${ }^{30}$ Jacek Malczewski to Juliusz, Twardowski [letter 2, dated 01.19.1911].

${ }^{31}$ XXXIX. Ausstellung der Vereinigung Bildender Künstler Österreichs Secession, Wien, November 1911-Jänner 1912; Malczewski's paintings no.: 6, 8, 10, 13, 14, 24, 28, 30, 32, 41, 42, 44-60, 6273; images of Malczewski's painting: no. 3. Portrait of Artist's Sister Bronisława, no. 5. Portrait of Count Wodzicki, no. 8. Portrait of Painter B. [Bryniarski], no. 10. Artist and Fame, no. 15. Vicious Circle. About the press criticism of the exhibition, KUDELSKA, Dukt pisma i pędzla, s. 538-539.

${ }^{32}$ Marceli S. Dobrowolski, Wiosna Młodej Polski. Wspomnienia, cz. V: Jacek Malczewski, Biblioteka Zakładu Narodowego im. Ossolińskich we Wrocławiu, man. 54691/II, vol. 5, 29-30.
} 
During some recent search queries in the Künstlerhaus archive, I have come across a file with the artist's records containing, but not only, 19 photographs of paintings, one reproduction pasted on a cardboard made by the Kraków's Zakład Kriegera and a photographic Carte de Visite (fragment of the painting with a muse and a boy with a large ladder in the background) with the following message, "Jacek Malczewski / á la / Ver Sacrum"33 (figs. 1-21).

The photographed images can be divided into four groups based on whether they are known today and whether they were selected for the exhibition from the original proposal. The first part contains works that were known and shown at the Secession: Der Frühling [1904], Der Künstler und der Ruhm [1898], Die Tochter des Künstlers [n.d.], Porträt des Grafen Wodzicki [1911], Verführung [1904], Die Schwester des Künstlers [1904, Bronisława], Das Gebet der Ellenai [n.d.], Selbsporträt [n.d.]. The second part contains works that are known but were not exhibited (not listed in the catalogue): Christus \& Samaritanerin [1911], Porträt Dr. Łepkowski, Samaritanaria [-sic, 1910], Dorfbrunnen [1905], Concert [1911], Der Blinde Faun [1910]. The third part consists of photographs of paintings listed in the exhibition catalogue but whose present location is unknown: Der Geiger [1905, an unknown variant of Stanisław Wójcicki’s portrait], Die Schwester des Künstlers [n.d., Helena] and two panels from a triptych that is not known today, Glory and Art: Triptik-Gloria \& Art I [1911], Triptik —Gloria \& Art III [1911]—catalogued under the common name of Triptychon. Finally, the fourth set consists of photographs of paintings (presented only in the submitted proposal; today unknown and not shown at the exhibition: Die Versuchung Christi [1911]; ${ }^{34}$ Persons 1 [1904], not listed and not reproduced anywhere else). The catalogue has also reproductions of paintings that are known today but which are not among the photographs in Malczewski's archive file Der Sohn des Künstlers [n.d.] and Zauberkreis [1890-1894].

\footnotetext{
${ }^{33}$ Files: Jacek Malczewski, Künstlerhaus Archiv, no ref., non-numbered sheets. The photographs, although no archival data is available, document the discussed exhibition at the Secession. They have made it accidentally into the current location. After 1945, the archives of the Secession and the Künstlerhaus were stored for some time in a building at 5 Karlsplatz; during that time, they were probably mixed up (information from Paul Rachler, curator of the Künstlerhaus Archiv, previously, an employee of the Wiener Secession Archiv). On the reverse, there are inscriptions in pencil: numbers not matching the catalogue ones, titles of images in German/English, sometimes dates).

${ }^{34}$ Listed in the catalogues of other exhibitions, repr. in Leon PINIŃSKI, "Wystawa zbiorowa prac Jacka Malczewskiego,” Sztuki Piękne 1 (1924/1925): 213.
} 
The list of identified catalogue titles and photographs shows that the artist submitted more paintings in his proposal (which was a standard procedure) than accepted for the exhibition: there were at least 50 of them and, most likely, even more. The oldest painting in this set was Vicious Circle, most of the works (six) were dated 1911, i.e. they were painted in the year of the exhibition. Among the oil paintings reproduced in the catalogue, only Malczewski's ones are figural. Most of the images depict landscapes, but none of them are Malczewski's, although he showed few of them at the exhibition (the titles are a clue, e.g. Sommer, Herbst).

This omission of Spring, also its absence from press reviews, is puzzling (now Spring. Landscape with Tobias). ${ }^{35}$ It was hung in the first, largest and most exposed room along with Wacław Szymanowski's sculptures (critically reviewed by the press). Even today, Spring amazes the viewer with the radical geometrization of forms and the choice of view showing in fact a degraded landscape instead of the beauty of spring in full bloom. Until now, it has been uncertain whether the canvas was shown in Vienna, but the uncovered photographic records seem to leave no doubt. ${ }^{36}$ Ignoring the work at the Secession in 1904 is hard to explain because the structure of the canvas marks a significant point in the development of synthetic landscape (or decorative, as Alexander Klee describes $\mathrm{it}^{37}$ ). This current is characteristic of the Central European belt stretching from Scandinavia, through Germany to Austria. It can also be seen in Polish and Czech painting. I think that it is not only due to nationality but mainly because of close associations and shared imagination, and using

\footnotetext{
${ }^{35}$ In the exhibition catalogue, there is no Privatbesitz label by the title of the painting, so, following the tradition of the place, it was intended for sale. This seems to contradict the information in the Catalogue of the Collections of the National Museum in Poznan (where the canvas is currently stored) that after 1909 the painting was the property of Wiktor Wawreczko of Kraków (Malarstwo polskie 1766-19145, comp. by Dorota Suchocka (Poznań: Muzeum Narodowe, 2005), item 661, source not provided).

${ }^{36}$ We have discussed many times with Dr Agnieszka Lawniczakowa that it seems unlikely that Malczewski did not send such a painting to such an important exhibition. However, we think that if Spring (many of Malczewski's canvases had the same title) had been shown in Vienna, it would have had to be noticed by critics.

${ }^{37}$ Alexander KLEE, "Über Formen und Massenvertheilung im Bilde" und die Entwicklung einer ornamentalen," in Formaliesierung der Landschaft. Hölzel, Meditz, Moll u.a. [Austellung Katalog], ed. Agnes Husslein-Arco, Alexander Klee (Wien: Belvedere, 2013), 24-38.
} 
a similar form. The characteristic shift in the design of painting landscapes coincided with a series of relevant graphics and texts in Ver Sacrum. Importantly, the trend clearly departed from impressionism as the dominant form of seeing and interpreting landscape. ${ }^{38}$

Polish landscape painting has not yet been discussed in this context, and this is by far an interesting area to explore (national, geographical and patriotic character of works prevail in the literature on the subject). Meanwhile, without going to deep into artistic contacts and using only a few of numerous examples, it can be pointed out that the similarity in designing space in Stanisławski's unique Beds (1897, National Museum in Kraków), [Landscape Woodcut] by Henneberg printed in Ver Sacrum and Malczewski's Spring is unquestionable. ${ }^{39}$

After the 39th Secession exhibition, Franz Dörnhöffer, director of the Moderne Galerie in Vienna, bought Malczewski's unknown Portrait with

\footnotetext{
${ }^{38}$ Adolf HöLzEL, "Über Formen und Massenvertheilung im Bilde," Ver Sacrum 4 (1901), H. 15: 243-254; Hugo HenneberG, "Graphik," Ver Sacrum 6 (1903), H. 1: 349-359. The theory and practice of landscape painting is associated with experimental photography and chemical innovations in graphic arts (Hennenberg presented this in Wiener Fotographische Blätter, ed. vom Camera-Club in Wien). Gummidrucke von Hugo Henneberg, Wien, Heinrich Kühn, Innsbruck, und Hans Watzek, Wien, Hrsg. F. Matthies-Masuren (Halle an der Saale: Verlag von Wilhelm Knapp, 1902); Hugo Henneberg 1863 1918 [Ausstellung Katalog Walfischgallery], ed. Rudolf Minichbauer, Wien 2011, online: http://galeriewalfischgasse.com/publikationen/Hugo_Henneberg.pdf (last access: 10.03.2017).

${ }^{39}$ Hugo HenNEBerG, "Graphik," 357, online: http://www.belvedere.at/jart/prj3/belvedere/data //documents/dokumente/downloads/digitale-bibliothek/ver-sacrum/1903 [last access: 19.03.2017]. There are clear similarities between Stanisławski's paintings and lithographs and the works by Henneberg. They are evident in the rhythm of the lines and the arrangement of colour masses as well as in the ways of reducing the realistic landscape features to conventional forms, getting near to the limit of recognition, as in water views filled with nostalgia (e.g. Poplars and Nach Sonnenuntergang: halftone, multi-colour autotype, in Photographisches Centralblatt 1898, on line: http://photoseed.com/ collection/group/photographisches-centralblatt-1898 (last access: 19.03.2017)). Photographs and graphics of this artist, also recognized in London and New York, are sometimes surprisingly close to Polish painting, e.g. Ruszczyc's Land (1898, National Museum in Warszaw) uses similar mass proportions as Henneberg's [Polowman] (Photograph 1890-1900, Gumbichromate print 1903, A. Stieglitz Collection, 1933, Acc. Nr. 33.43.413, online: http://www.metmuseum.org/art/ collection/search/ 267830 (last access: 15.03.2017)). Due to the many exhibitions and repetitive prints and reprints of Henneberg's work, it is not always possible to arrange the item chronologically. However, parallelism in the selection of scenes, links between motifs, frames and styles of views is crucial as a manifestation of shared topics.
} 
Allegorical Figures. ${ }^{40}$ Preserved photographs suggest that it was one of two compositionally identical images of the artist's sisters. Malczewski agreed to Dörnhöffer's offer to exchange the canvas "for another work." He sent him Portrait of the Wife with Fauns (today in the Museum Belvedere) with almost identical make-up as the portraits of Helena Karczewska and Bronisława Malczewska, however, its bright colours and extraordinary lightness and gentleness of the brush work make it definitely different. Around mid-1911, a technically similar work was created, Doubting Thomas, a portrait of Malczewski as Jesus and Vlastimil Hofman as the apostle. According to Hofman, the painting was the master's manifestation of doubt whether he would ever be exhibiting successfully in Vienna. Meanwhile, shortly after the opening of the winter exhibition, as reported by the Polish press, the board of the Secession congratulated to the artist on the success of the exhibition. ${ }^{41}$

As regards the chronological reconstruction of events related to Malczewski's Viennese studio, there is one published letter on this matter that needs to be recalled. On 2 August 1912, an official reminder was sent to pay the outstanding rent from November 1911. ${ }^{42}$ Twardowski's records reveal extra facts in this respect. In response to the authorities, Malczewski promised the repayment of the debt and explained that the late payment of one part of the rent resulted in arrears spanning several months; he requested to be billed on 1 October 1912. He wrote,

I managed to obtain the Prater studio only because of your kindness. There was a time when I was entertaining the idea of moving to Vienna and working in Prater.

But I had to abandon this plan. First, it turned out that painting studios in Prater unfortunately do not satisfy the specific requirements of my working style: insufficient light and space and no possibility of painting in the open.

Second, I had to take care of my professorship, and this year I have been nominated rector, and the studio in Prater remains empty [sic]... I can pay for the studio until 1 October 1912, but after that I will leave it if I may.

${ }^{40}$ Dyrekcja Moderne Galerie do J. Malczewskiego, Special Collections of the Institute of Art, Polish Academy of Sciences, man. 54, 67-69; KudELSKA, Dukt pisma i pędzla, 537.

${ }^{41}$ KudELSKA, Dukt pisma i pędzla, 760, Column: From the Palace of Fine Arts: M.K., "Głosy prasy obcej o sztuce polskiej," Krakowski Miesięcznik Artystyczny 10 (1911): 110-111.

${ }^{42}$ KudELSKa, Dukt pisma i pędzla, 539-540. 
Please, send me, or rather have it sent, the total outstanding amount due on 1 October 1912 as rent, and I will pay it and leave the studio, which I, a stranger, owe to you and I want to thank again wholeheartedly... ${ }^{43}$

It follows, first of all, that when finishing with the Vienna studio, Malczewski did not yet know Twardowski personally, despite his previous written declarations that he would come to thank him in person during his stay in Vienna.

Second of all, the artist regularly paid for renting the premises in Prater for some indefinite time. It should be noted, however, that the dates of his letters to the authorities overlap with changes in his employment status at the Kraków Academy of Fine Arts. ${ }^{44}$ The first (dated 23 January 1900) proves that the artist began his efforts in this regard during his first employment at the Academy of Fine Arts, which he eventually abandoned without prior notice to the faculty in October 1900. According to the correspondence, the artist had been considering it at least since the end of June, while the January date of the letter reveals his desire to become completely independent of the Kraków artistic community already in early 1900. Therefore, there is a coincidence with the first letter to Twardowski regarding the rent of the studio. Consequently, the studio was possible rented in early 1900, but it is not certain for how long.

Later, attempts were made to persuade the painter to resume work for the academy, but he kept refusing. After the reform, he returned as professor, which, based on the cited letter, prompted him to vacate the Vienna studio. However, looking more carefully at the dates allows several chronological nodes to be identified. 9 March 1910 is relevant because this is when the governance of the Academy of Fine Arts unanimously decided to apply to the relevant ministry for consent to Malczewski's employment as professor. In my opinion, based on Malczewski's previous behaviour and requirements, that decision must have been agreed with him in advance, which may shift this date somewhat backwards. Aware of previous unpleasant experience with the Academy of Fine Arts, the artist suspended his decision to assume his teaching duties until the official governmental approval, which arrived on 27 October

\footnotetext{
${ }^{43}$ J. Malczewski to Juliusz Twardowski [letter 3, dated 1.10.1912].

${ }^{44}$ On Malczewski's relationship with the Academy of Fine Arts until 1918, see KudELSKA, Dukt pisma i pędzla, 378-404.
} 
1911. Protracted financial formalities delayed the beginning of his employment until the second semester (February 1912), which might have led him to doubt whether maintaining a studio in Vienna was reasonable. ${ }^{45}$

Considering the dates of the letters, several possibilities should be explored as to when he actually used it. The first is the least likely: the artist occupied the same studio for around 12 years (19 January 1900-1 October 1912). Another option is that he used the premises but not on a regular basis. That he rented two different places during these years should not be ruled out, either. However, "to have at your disposal" is not tantamount to the actual use of the premises. What is certain, the painter rented a studio for a period from the beginning of 1911 (or from December 1910, perhaps in connection with the 39th Secession exhibition) until 1 October 1912. He did not pay the rent on time and even in 1913 he tries to explain to Twardowski the reasons for arrears. ${ }^{46}$

Is it possible that artist's friends did not know about his Vienna studio? If even nosy Kossak didn't know, it is possible. It is also important that the artist maintained that official correspondence only in person and for many years while many similar matters in that time were handled by his secretary, Piotr Dobrzański. It naturally follows that Jacek Malczewski was able to take care of his everyday business on his own, despite his commonly held image of a pretentious dreamer. He also considered working abroad.

He justifies his resignation from the Prater studio by various "inconveniences," such insufficient light and "[no] space and no possibility of painting in the open." While the former reason is difficult to verify today, the other complaint is probably a form of excuse. Prater was famous for its vast outdoor space, and part of the park was actually a wild wetland. It was those views of Danube wetlands that made Tina Blau introduce post-impressionism experiments to Vienna's stylistic exhibitions. ${ }^{47}$

\footnotetext{
${ }^{45}$ From October 1896 to June 1900, Malczewski worked at the Academy of Fine Arts, headed by Julian Fałat, for the first time. In October 1910, Teodor Axentowicz took the office of rector, and Malczewski accepted his proposal to become a professor; in the academic years 1912/1913 and 1913/1914, he was academy rector. KuDELSKA, Dukt pisma i pędzla, 378-405.

46 J. Malczewski to Juliusz Twardowski [letter 4, dated 27.02.1913].

${ }^{47}$ On the renting of a studio in Prater by Tina Blau and her outdoor paintings, see Julie M. JOHNSON, The Memory Factory: The Forgotten Women Artists of Vienna 1900 (West Lafayette, Indiana: Purdue University Press, 2012), 24-25, 232.
} 
After the outbreak of World War I, the artist probably regretted being away from Prater. Like many others, he fled Kraków for fear of the approaching warfare and administrative restrictions. While in Vienna, he wanted to prove his loyalty to Austria to a high-level official. At the beginning of September 1914, Malczewski wrote to Twardowski from Charzewice,

I am writing this letter from a village where I settled, as a worshipper of muses, who has almost nowhere to go these days. And from here I am writing...that the question of my salary has changed due to some recent developments. I will come to Vienna and take an oath there in the ministry, and you will help me with this. Is that fine with you?

He also asks if he can come with the family and tells that he intends to keep working,

...to leave something in art. My Kraków study has been seized for hospital. Maybe the Vienna Academy can offer me some makeshift studio and a job for a few months.

Would you please have a word with the Minister of Education, $\mathrm{Mr}$ [Tesch?] Lanckoroński, maybe Duchess Maria Lubomirska. Is that fine with you?

Please, help me in these hard times and as a reward for my work so far allow me to practice my profession for a short while... ${ }^{48}$

On the margin of the letter, Twardowski notes, "Pochwalski," which suggests that Malczewski's admission to the academic studio of Kazimierz Pochwalski was Twardowski's idea and not the result of host's courtesy and friendship of other artists, as has been held to date. Immediately after returning to Kraków, Malczewski sent Twardowski a brief but heartfelt thanks because he had not met him in Vienna. ${ }^{49}$

The last letter to Twardowski was sent from Lusławice, where Malczewski was spending holidays with his sisters. He expressed his gratitude for remembrance and holiday wishes and ended with the words,

\footnotetext{
${ }^{48}$ J. Malczewski to Juliusz Twardowski [letter 5, dated 07.09.1914].

${ }^{49}$ J. Malczewski to Juliusz Twardowski [letter 6, dated 27.06.1915], letterhead: C.K. ASP w Krakowie.
} 
True friendship and genuine kindness are rare in human life, so many thanks again. Sincerely grateful and with loving memory, Jacek Malczewski. ${ }^{50}$

The documents and photographs discussed are merely a small step but, still, a step forward in the search of facts from Jacek Malczewski's life and creative work. They cast some new light on the artist's activities outside Kraków and domestic exhibitions.

In a broader perspective, Malczewski's experience with the Prater studio demonstrate how much information can still be retrieved from Viennese archives and how important the Austrian contacts were for the development of a complete picture of Polish art in the late $19^{\text {th }}$ and early $20^{\text {th }}$ century.

\section{LIST OF FIGURES}

1. Jacek Malczewski, Der Frühling [1904], Krünstlerhaus Archive

2. Jacek Malczewski, Der Künstler und der Ruhm [1898], Künstlerhaus Archive

3. Jacek Malczewski, Die Tochter des Künstlers [n.d.], Künstlerhaus Archive

4. Jacek Malczewski, Porträt des Grafen Wodzicki [1911], Künstlerhaus Archive

5. Jacek Malczewski, Verführung [1904], Künstlerhaus Archive

6. Jacek Malczewski, Die Schwester des Künstlers [1904, Bronisława], Künstlerhaus Archive

7. Jacek Malczewski, Das Gebet der Ellenai [n.d.], Künstlerhaus Archive

8. Jacek Malczewski, Selbsporträt [n.d.], Künstlerhaus Archive

9. Jacek Malczewski, Christus \& Samaritanerin [1911], Künstlerhaus Archive

10. Jacek Malczewski, Porträt Dr. Łepkowski, Samaritanaria [1910]

11. Jacek Malczewski, Dorfbrunnen [1905], Künstlerhaus Archive

12. Jacek Malczewski, Concert [1911], Künstlerhaus Archive

13. Jacek Malczewski, Der Blinde Faun [1910], Künstlerhaus Archive

14. Jacek Malczewski, Der Geiger [1905, unknown variant of the portrait of Stanisław Wójcicki], Künstlerhaus Archive

15. Jacek Malczewski, Die Schwester des Künstlers [n.d., Helena], Künstlerhaus Archive

16. Jacek Malczewski, Triptik - Gloria \& Art I [1911], part one of the triptych, Künstlerhaus Archive

17. Jacek Malczewski, Triptik - Gloria \& Art III [1911], part three of the triptych, Künstlerhaus Archive

18. Jacek Malczewski, Die Versuchung Christi [1911], Künstlerhaus Archive

19. Jacek Malczewski, Persons 1 [1904], Künstlerhaus Archive

20. Jacek Malczewski, Carte de Visite [n.d.], Künstlerhaus Archive

\footnotetext{
${ }^{50}$ J. Malczewski to Juliusz, Twardowski [letter 7, dated 17.06.1925].
} 
21. Hugo Henneberg, "Graphik," Ver Sacrum 6(1903), issue 1, 353, by courtesy of: Bibliothek Österreichische Galerie Belvedere, Digital Library: https://www.belvedere.at/jart/prj3/belvedere/data// documents/dokumente/downloads/digitale-bibliothek/ver-sacrum/1903_versacrum_v06_72dpi.pdf.

\section{BIBLIOGRAPHY}

XV. Ausstellung der Vereinigung Bildender Künstler Österreichs Secession, Wien, Nov.-Dez. 1902.

XXXIX. Ausstellung der Vereinigung Bildender Künstler Österreichs Secession. Wien November 1911Jänner 1912. Wien: Universitätsbibliothek Heidelberg, 1911.

[Column: Popular Chronicle], "Nauka i literatura we Lwowie." Tygodnik Ilustrowany 18 (1903), (first six months).

AichELBURG, Wladimir. "Die Künstlergenossenschaft und ihre Rivalen Secession und Hagenbund.” In IDEM, Das Wiener Künstlerhaus 1861-2001. Band 1. Wien: Österreichischer Kunst- und Kulturverlag, 2003.

“An Undervalued Place of often Unwelcome Painters. Polish Art in the Hagenbund." In A European Network of Modernism (1900 to 1938). Trans. by Russel Stockman, Jeremy Gains [German into English], ed. Agnes Husslein-Arco, Matthias Boekl, Harald Krejci. Vienna: Belvedere, 2014.

Arkadien und angenehme Feinde. Die Bildhauerateliers im Prater, ed. Werner Würtinger. Wien: Revolver Publishing, 2011.

BRZYSKI, Anna. "Vienna Secession, Hagenbund, Sztuka, Mánes: Competition and Strategic Collaboration among Central European Art Groups.” Centropa 11, issue 1 (2011).

Dobrowolski, Marceli S. Wiosna Młodej Polski. Wspomnienia, cz. V, Jacek Malczewski. Biblioteka Zakładu Narodowego im. Ossolińskich we Wrocławiu, manuscript 54691/II, vol. 5.

Dyrekcja Moderne Galerie do J. Malczewskiego. Special Collections of the Institute of Art, Polish Academy of Sciences in Warsaw, manuscript 54.

Files: Jacek Malczewski, Künstlerhaus Archiv, no ref., non-numbered sheets.

Fux, Herbert. Japan auf der Welfausstellung in Wien 1873. Wien: Österreichisches Museum für angewandte Kunst, 1973.

Gummidrucke von Hugo Henneberg, Wien, Heinrich Kühn, Innsbruck, und Hans Watzek, Wien, ed. Fritz Matthies-Masuren. Halle an der Saale: Verlag von Wilhelm Knapp, 1902.

Gustav Klimt Dokumentation, ed. Christian M. Nebehay. Wien: Christian M. Nebehay, 1919.

Henneberg Hugo, http://www.belvedere.at/jart/prj3/belvedere/data//documents/dokumente/downloads /digitale-bibliothek/ver-sacrum/1903 (last access: 19.03.2017).

HenNeberG, Hugo. “Graphik.” Ver Sacrum 6 (1903), book 1 (no text).

HEVESI, Ludvig. "Vereinigung Bildender Künstler Österreichs.” Ver Sacrum (Januar) book 1 (1898).

HEVESI, Ludvig. Österreichische Kunst im Neunzechten Jahrhundert. Leipzig: Seemann Leipzig, 1903.

HöLZEL, Adolf. "Über Formen und Massenvertheilung im Bilde.” Ver Sacrum 4, book 15 (1901). 
"Hugo Henneberg 1863-1918“ [Ausstellung Katalog Walfischgallery], Hrsg. Rudolf Minichbauer. Wien 2011, online: http://galerie-walfischgasse.com/publikationen/Hugo_Henneberg.pdf (last access: 10.03.2017).

J. Malczewski do Wiener Secession. Wien. Archiv der Secession, 25.4.6. / 6052.

Johnson, Julie M. The Memory Factory: The Forgotten Women Artists of Vienna 1900. West Lafayette, Indiana: Purdue University Press, 2012.

"Karol Lanckoroński i jego spuścizna rękopiśmienna w zbiorach Austriackiej Biblioteki Narodowej." In Karol Lanckoroński i jego czasy. Varia. Lanckoroniana. Vol. 1, ed. Anna Ziemlewska. Vienna: Stacja Naukowa PAN, 2015.

Katalog Ausstellung im Künstlerhause. 22. Dezember 1895. [foreword] Dr Cyprianus Bodenstein, I und II. Gräflich J. Milewski'sche Sammlung. Wien: Forgotten Books, 2018 [1895].

Katalog der polnischen Künstlerausstellung, mit einem Vortwort von Prof. dr. Jan v. Bołoz Antoniewicz. Wien: Künstlerhaus [11. April bis 10. Mai] 1915.

KLEE, Alexander. "Über Formen und Massenvertheilung im Bilde" und die Entwicklung einer ornamentalen." In Formaliesierung der Landschaft. Hölzel, Meditz, Moll u.a., [Ausstellung Katalog], ed. Agnes Husslein-Arco, Alexander Klee. Wien: Belvedere, 2013.

Kossak Wojciech, Listy do żony i przyjaciót (1883-1942). Selection, compilation, introduction, notes and indexes by Kazimierz Olszański. Vol. 1. Kraków: Wydawnictwo Literackie, 1985.

KuDELSKA, Dorota. "Polnischen Malern aus München im Gemäldeausstellungen im Wiener Künstlerhaus." In Das Exotische Europa: Heimatsmotiven Künstler in München, ed. Eliza Ptaszyńska. Suwałki: Muzeum Okręgowe w Suwałkach, 2015 (also the Polish version available).

KuDELSKA, Dorota. "Wiedeńskie kontakty 'Sztuki'—z zapisów w Księdze Protokołów Towarzystwa Artystów Polskich.” Annales UMCS, sec. FF, 2016 [in print].

KudELSKA, Dorota. Dukt pisma i pędzla. Biografia intelektualna Jacka Malczewskiego. Lublin: Wydawnictwo KUL, 2008.

KudELSKA, Dorota. Malczewski. Obrazy i Stowa. Warszawa: Wydawnictwo W.A.B., 2012.

Lanckoroniana. Vol. 1-4, ed. Bogusław Dybaś. Wiedeń: Stacja Naukowa PAN, 2015.

Malarstwo polskie 1766-1945. Katalog. Compiled by Dorota Suchocka. Poznań: Muzeum Narodowe, 2005.

Officieller Kunst-Catalog Welt Ausstellung 1873 in Wien. Wien: Verl. der General-Direction, 1873.

PARTSCH, Susanna. Klimt. Życie i twórczość. Transl. by Anna Kozak. Warszawa: Arkady, $1998\left(1^{\text {st }}\right.$ ed. in German, 1993).

PAszkiewiCZ, Mieczysław (comp.). "Listy Jacka Malczewskiego do Karola Lanckorońskiego.” Roczniki Historii Sztuki 18 (1990).

„Photographisches Centralblatt” 1898, online: http://photoseed.com/collection/group/photographischescentralblatt-1898 (last access: 19.03.2017).

PINIŃSKI, Leon. "Wystawa zbiorowa prac Jacka Malczewskiego.” Sztuki Piękne 1, issue 5 (1924/1925).

Siedem listów Jacka Malczewskiego do Juliusza Twardowskiego. Kazimierz Wielki Univeristy. Juliusz Twardowski's Archive (1900-1944), manuscript 26, non-numbered sheets. 
TABORSKI, Roman. Wśród wiedeńskich poloników. Kraków: Wydawnictwo Literackie, 1974.

Wiener Fotographishe Blätter, ed. vom Camera-Club in Wien.

WinIEWICZ-WolsKa, Joanna. Karol Lanckoroński-,ostatni humanista wśród europejskiej arystokracji”, http://www.viennapan.org/index.php/badania/lanckoronski/o-karolu-lanckoronskim/ biografia (last access: 15.04.2016).

"Z pałacu Sztuk Pięknych: M.K., Głosy prasy obcej o sztuce polskiej.” Krakowski Miesięcznik Artystyczny 10 (1911).

\section{JACEK MALCZEWSKI AND VIENNA: NEW FACTS}

\section{Summary}

The article presents, apart from the well-known facts concerning Malczewski's connections with Viennese institutions and art circles, unknown archive materials, including: 1. letters exchanged between the artist and Juliusz Twardowski (a ministerial official) regarding the lease of a workshop at the Prater district of Vienna (letters were written between 1900-1913 and in 1925); 2. photographic documentation (19 items from the years 1890-1911) of the XXXIX. Ausstellung der Vereinigung Bildender Künstler Österreichs Secession in Vienna that featured 40 paintings by Malczewski and the sculpture Procession to Wawel by Wacław Szymanowski. The manuscripts indicate that Malczewski kept a secret atelier abroad and he most definitely worked there (it was either during one prolonged period, or two periods each lasting a few years). It contradicts the naïve opinions that Malczewski, being a patriot, could not stand separation from his homeland.

Photographs with dates and signatures complete the information from the catalogue; they allow for the matching of the ambiguous titles with photographs, and consequently help to identify the paintings shown at the exhibition. Some paintings presented in the photos are not known today, therefore the photographs constitute valuable iconographic material. The documents prove, for instance, that Spring. Landscape with Tobias (1904) was presented in Vienna. It is startling that the painting's synthetic form was not acknowledged by the critics in Vienna. Just after the World War I, Malczewski wrote a letter to the President of the Wiener Secession in which he stated that the war had not been beneficial to any of the martyred and agitated nations and he had hoped for cooperation between the artists in the time of peace that would not be shaped by national interests or politics.

Key words: Jacek Malczewski; Polish painting in Vienna; Wiener Secession.

Translated by Konrad Szulga

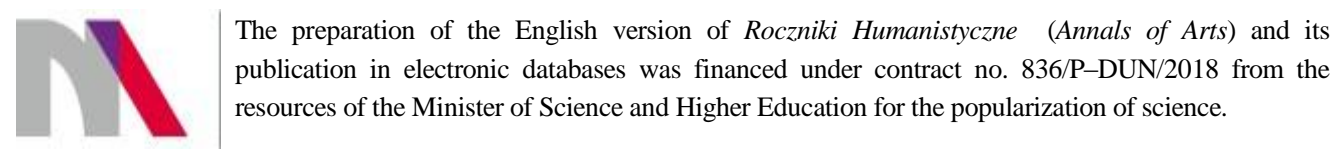




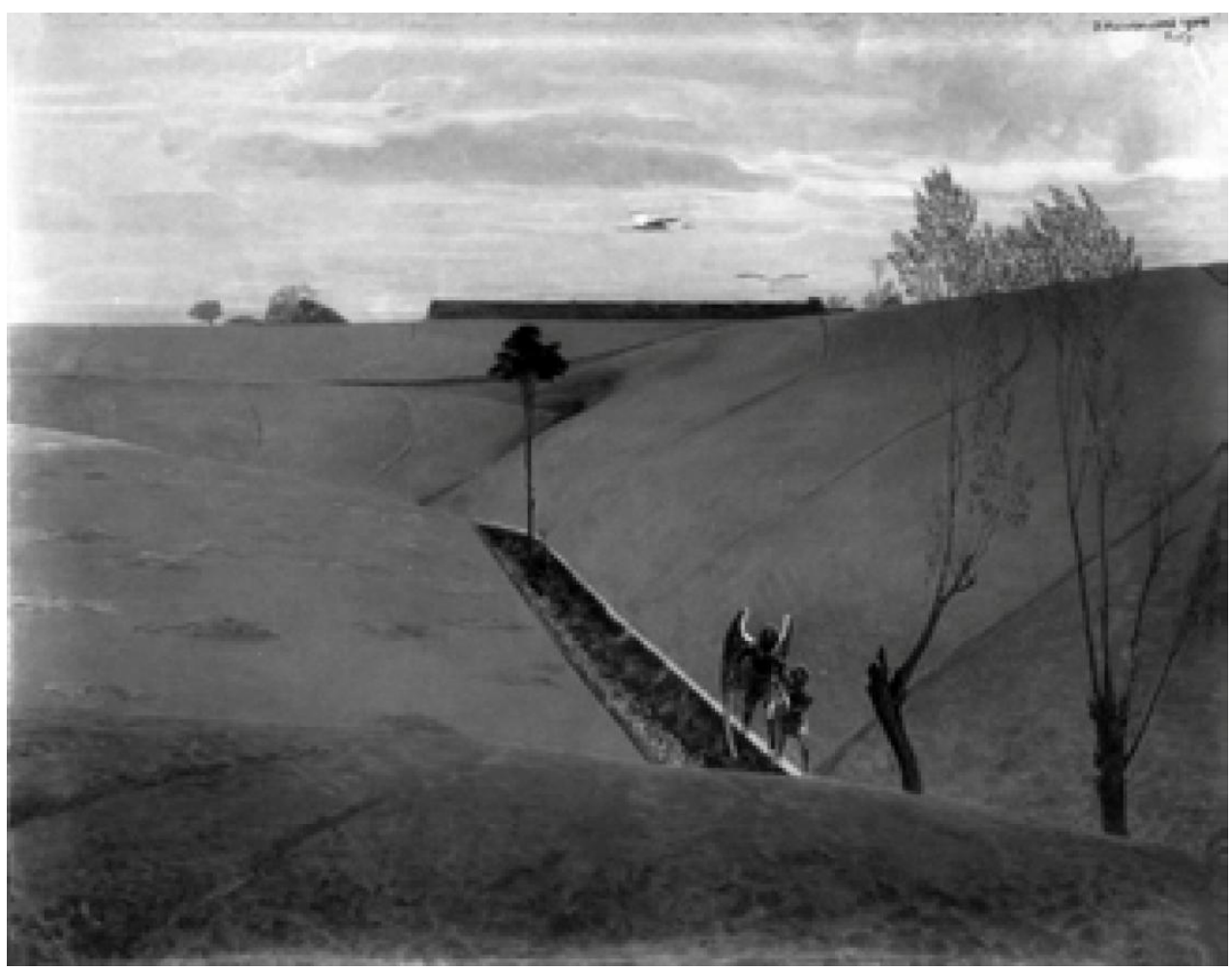

1. Jacek Malczewski, Der Frühling [1904], Krünstlerhaus Archive 


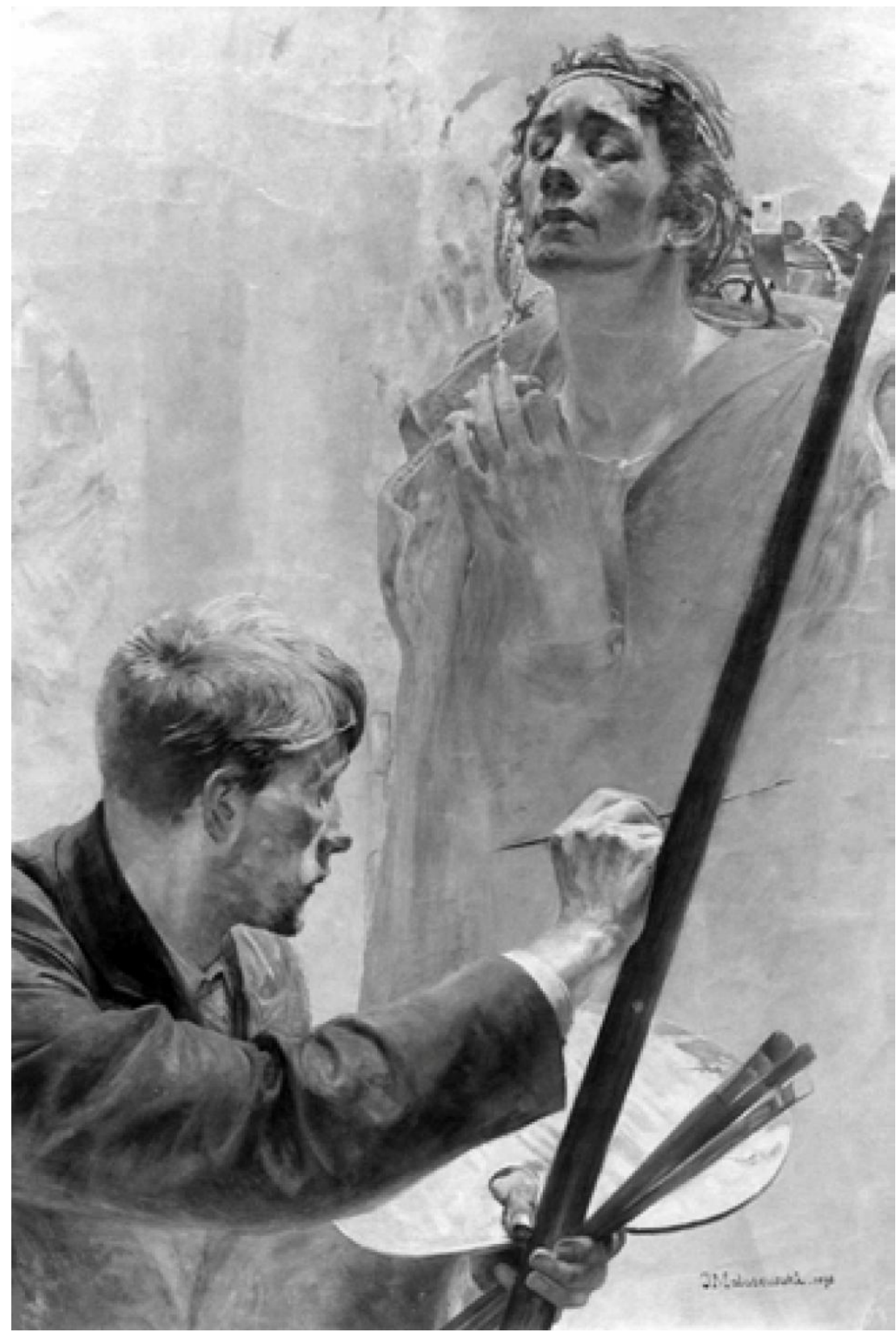

2. Jacek Malczewski, Der Künstler und der Ruhm [1898], Künstlerhaus Archive 


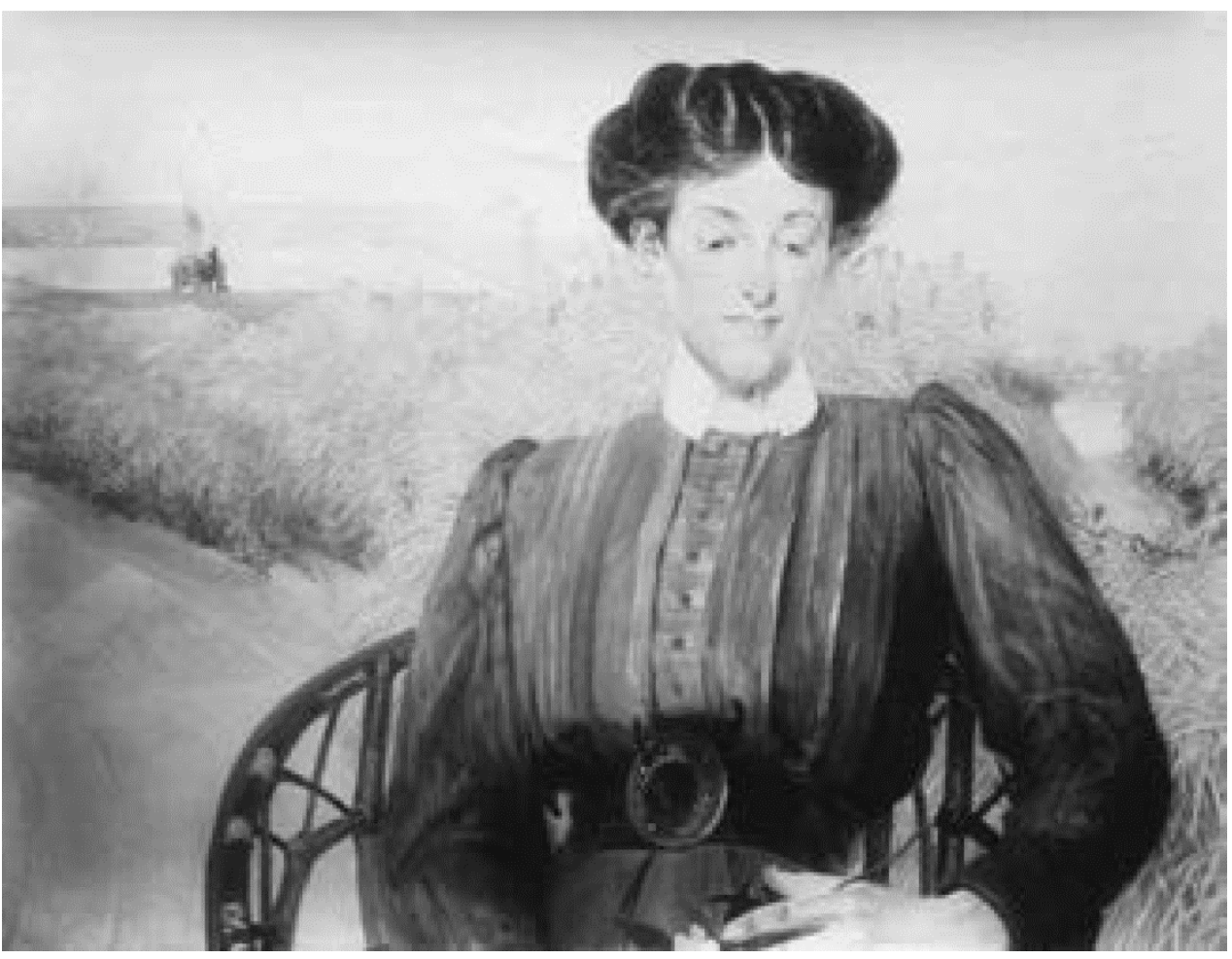

3. Jacek Malczewski, Die Tochter des Künstlers [n.d.], Künstlerhaus Archive 


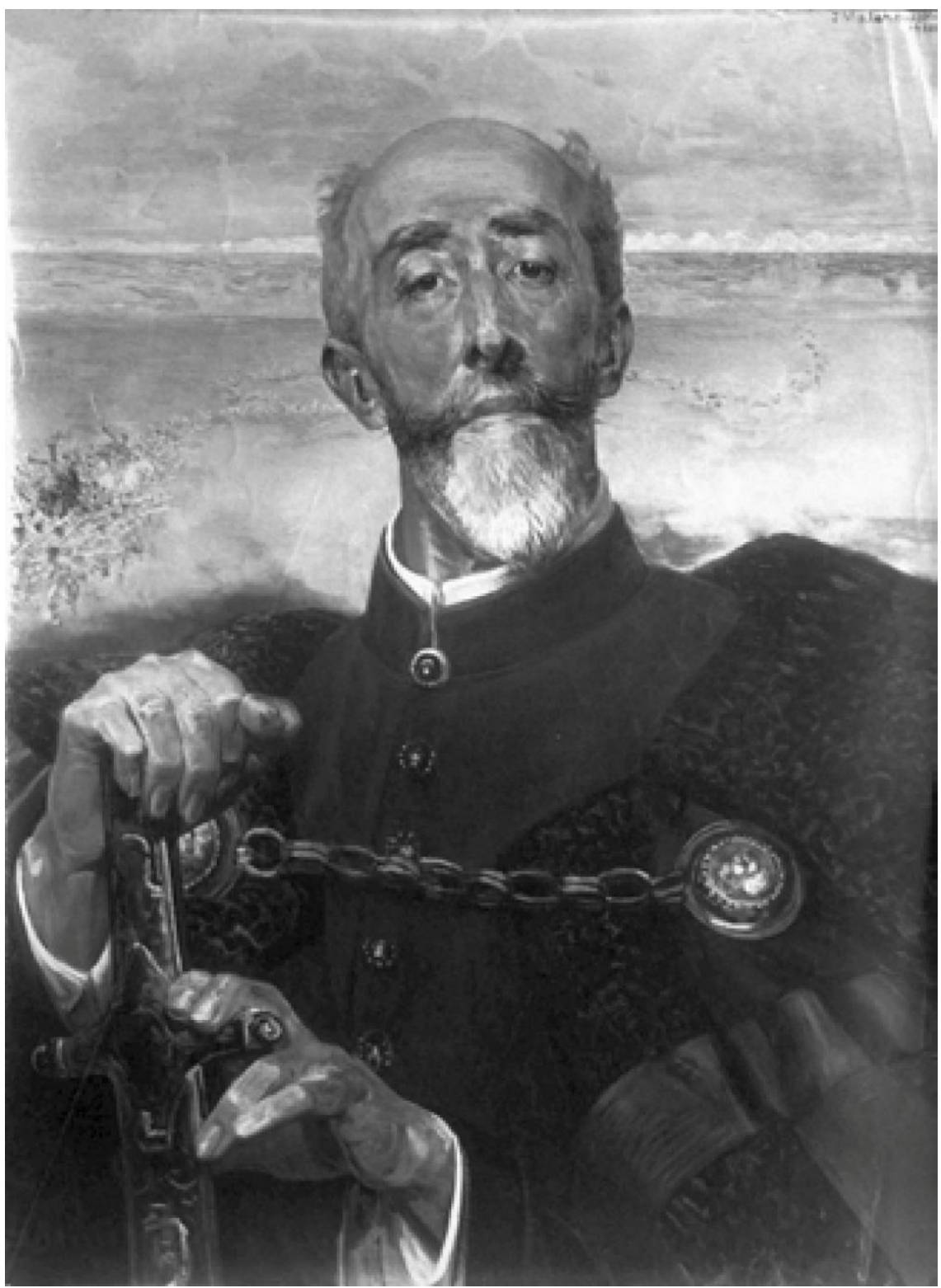

4. Jacek Malczewski, Porträt des Grafen Wodzicki [1911], Künstlerhaus Archive 


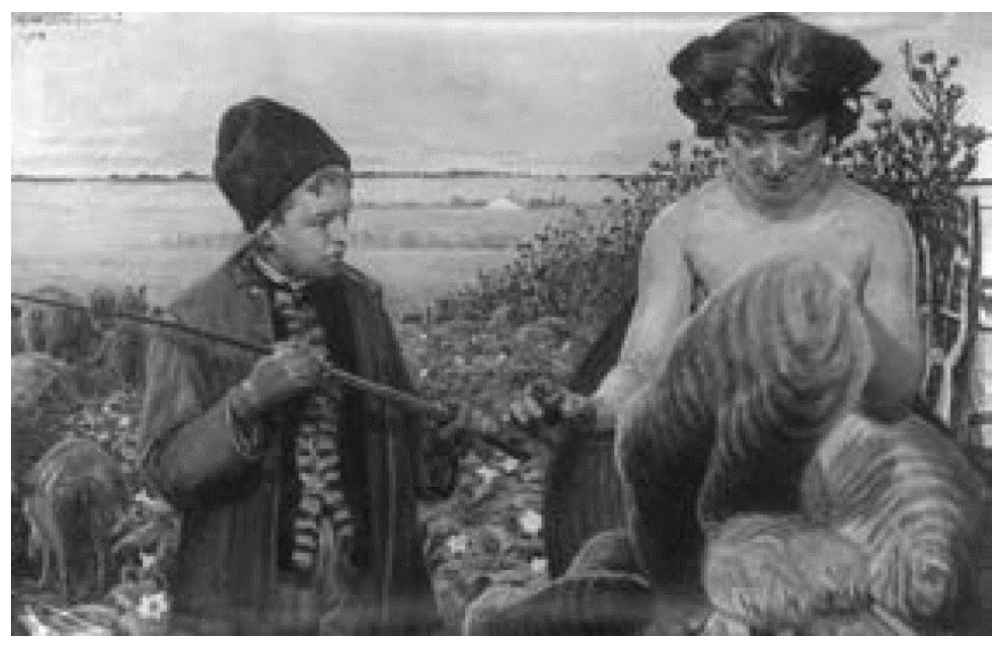

5. Jacek Malczewski, Verführung [1904], Künstlerhaus Archive

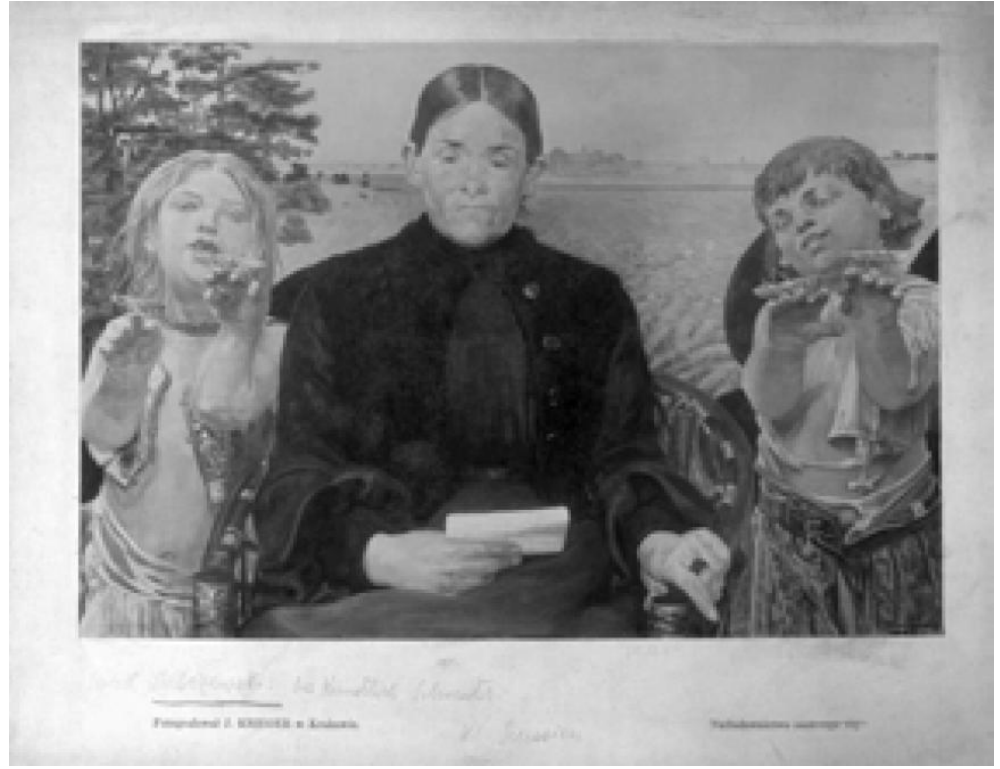

6. Jacek Malczewski, Die Schwester des Künstlers [1904, Bronisława], Künstlerhaus Archive 


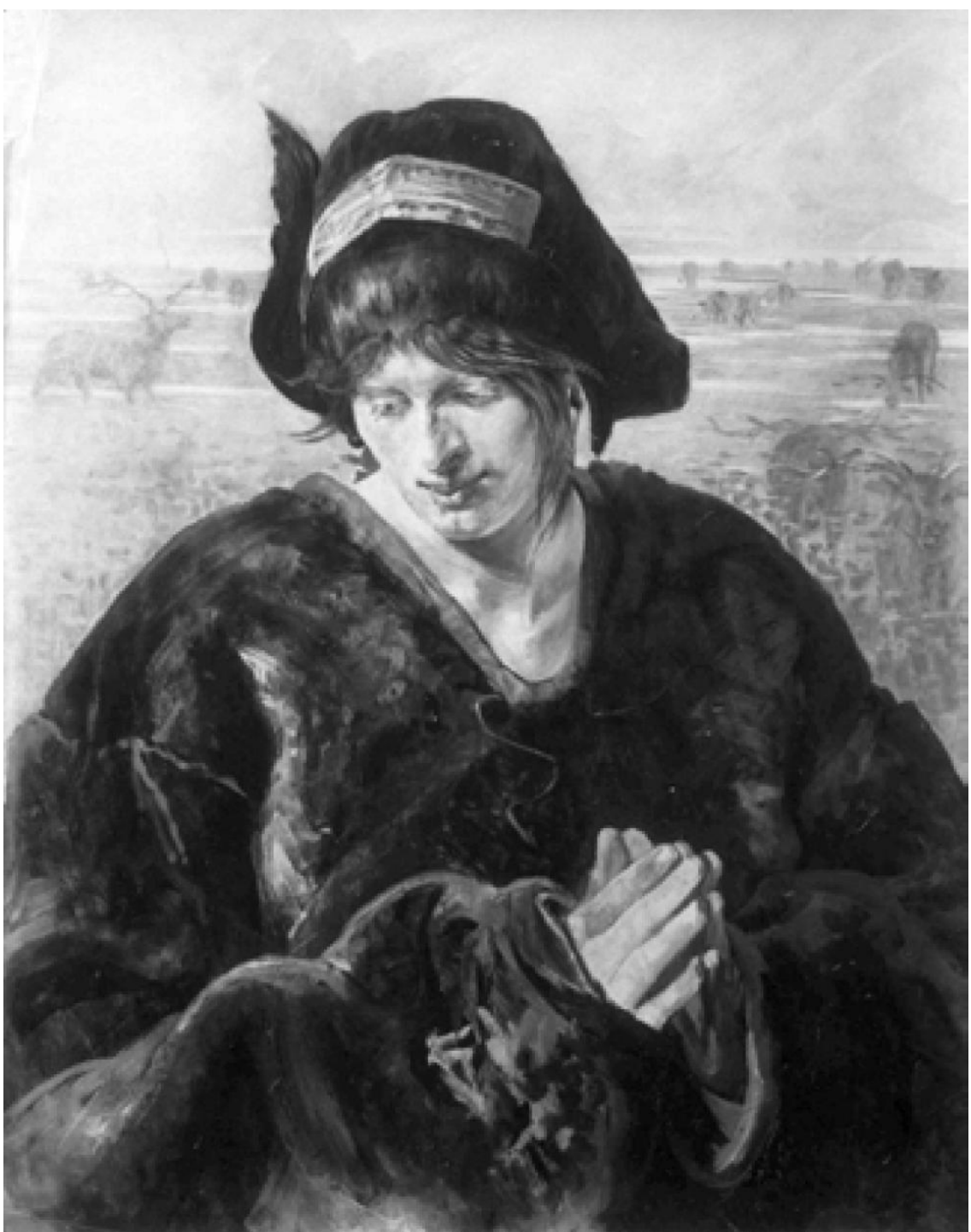

7. Jacek Malczewski, Das Gebet der Ellenai [n.d.], Künstlerhaus Archive 


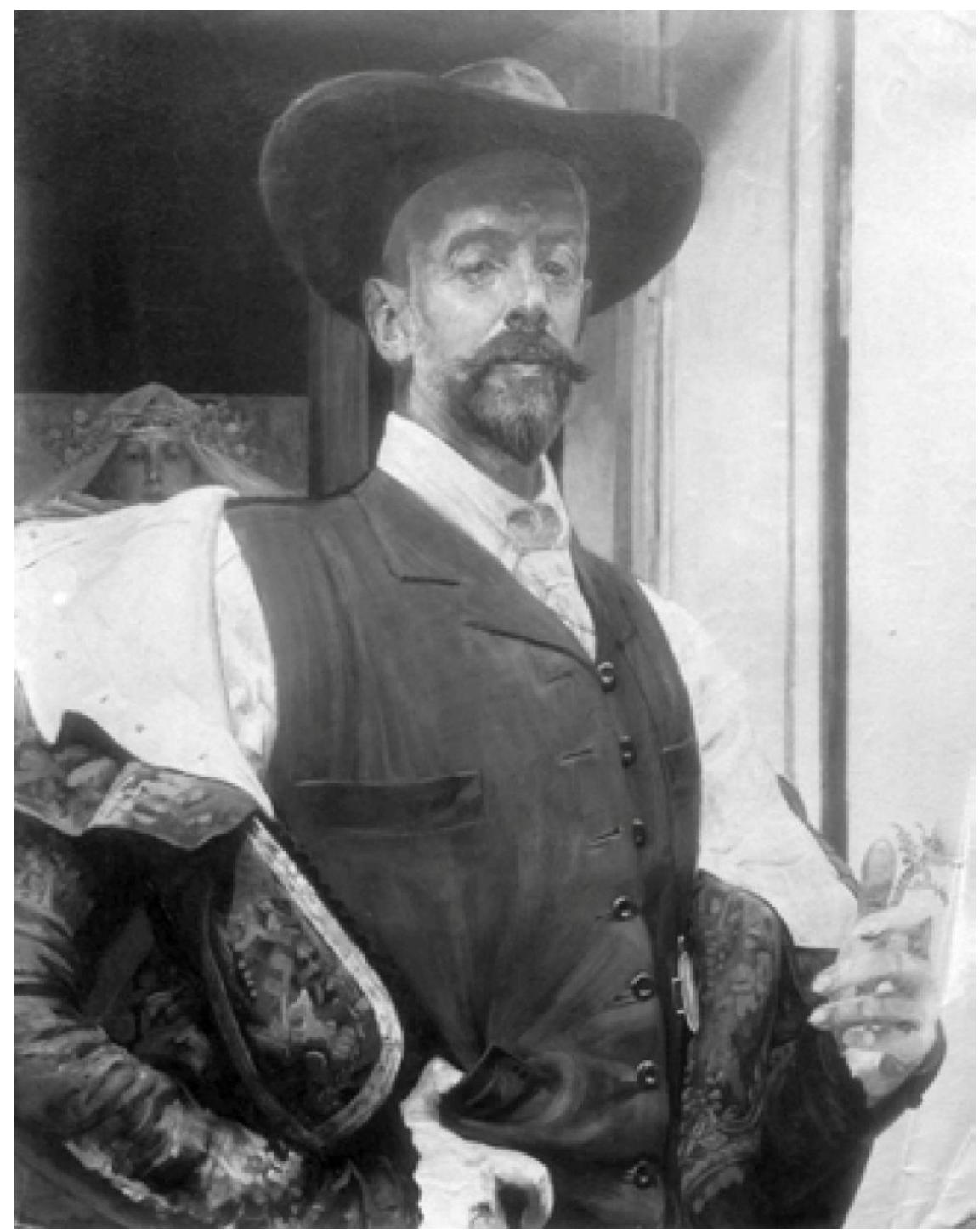

8. Jacek Malczewski, Selbsporträt [n.d.], Künstlerhaus Archive 


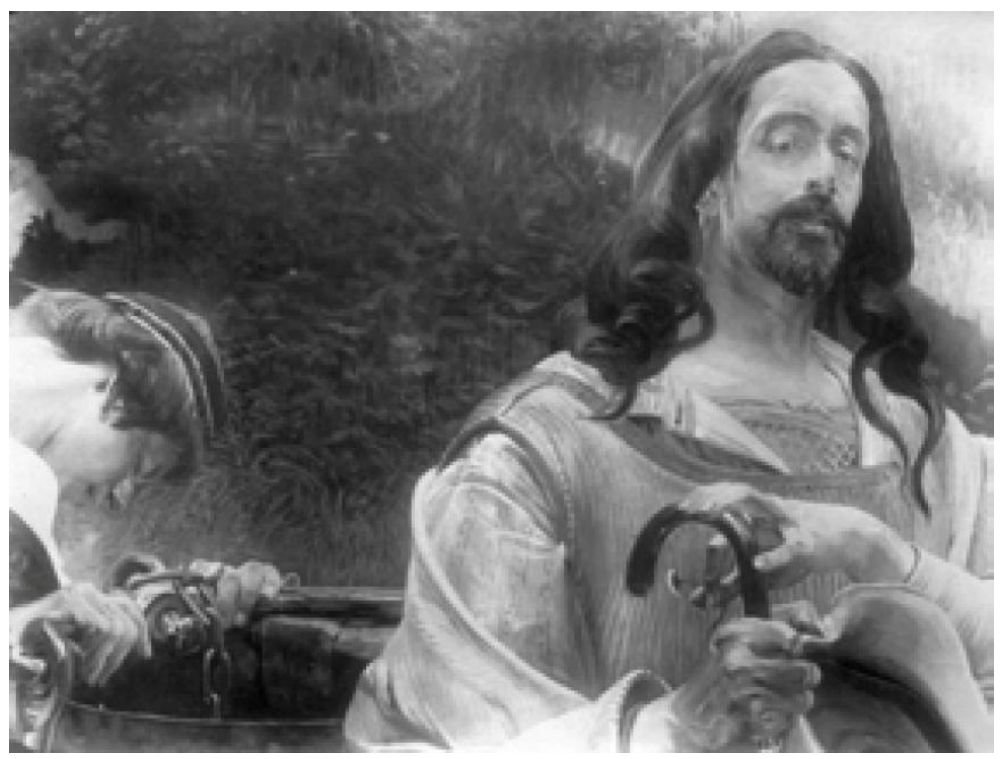

9. Jacek Malczewski, Christus \& Samaritanerin [1911], Künstlerhaus Archive

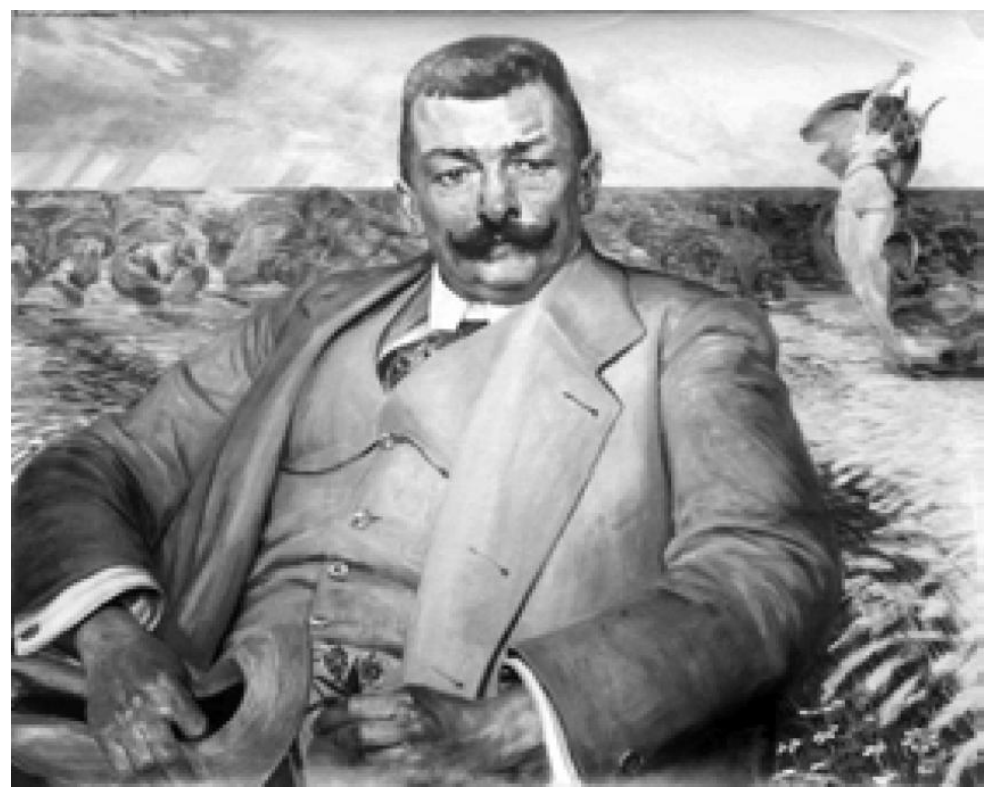

10. Jacek Malczewski, Porträt Dr. Łepkowski, Samaritanaria [1910] 


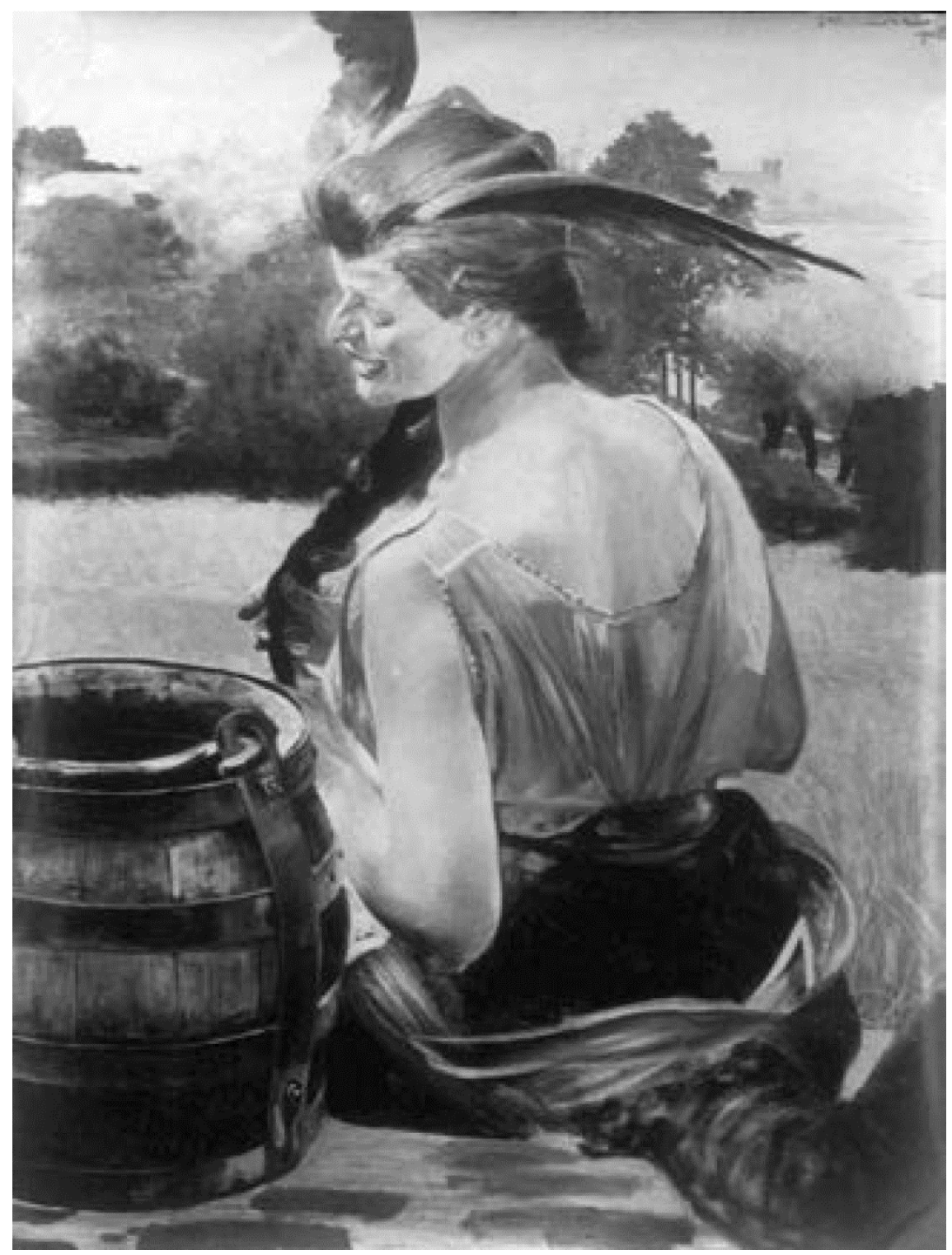

11. Jacek Malczewski, Dorfbrunnen [1905], Künstlerhaus Archive 


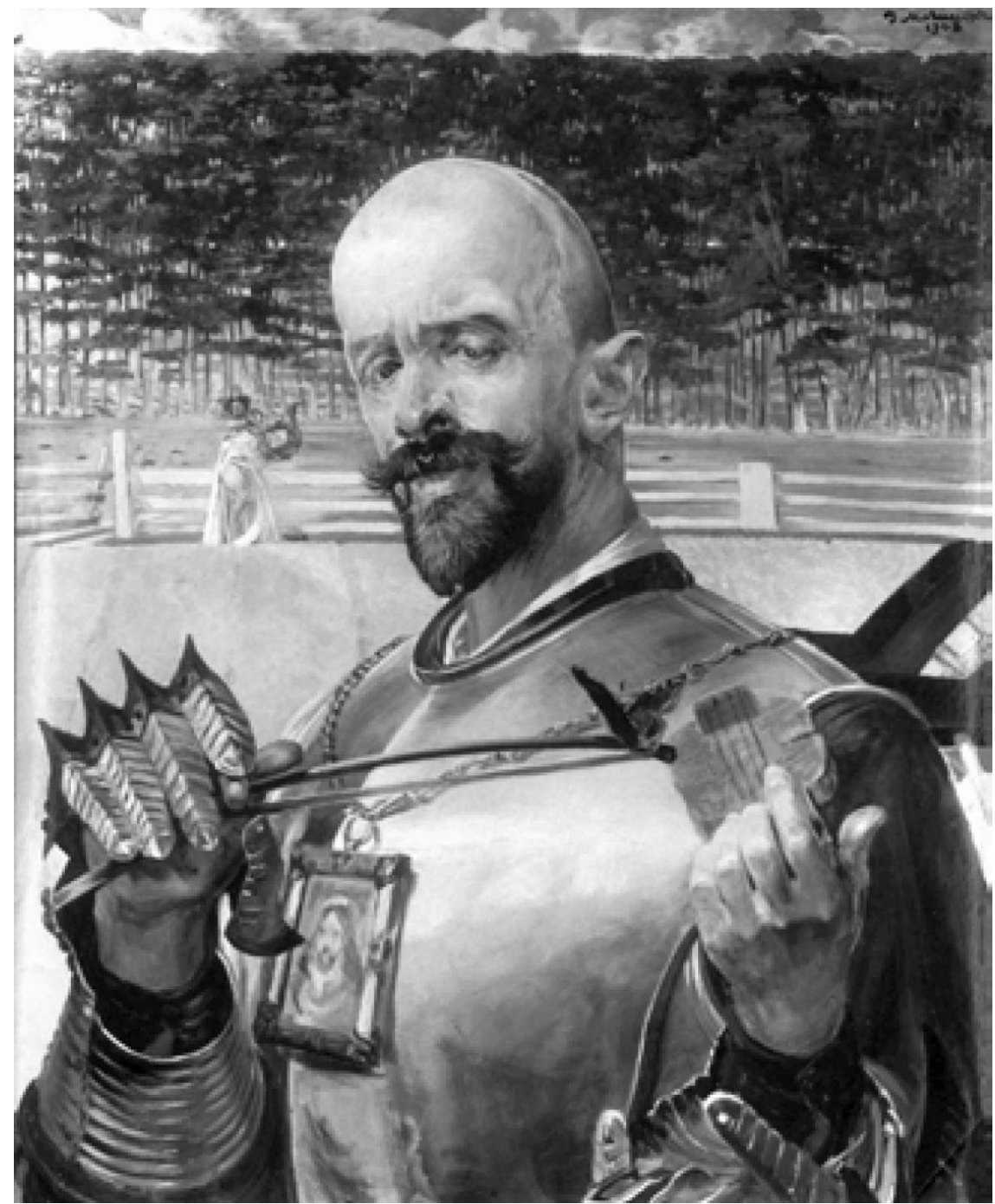

12. Jacek Malczewski, Concert [1911], Künstlerhaus Archive 


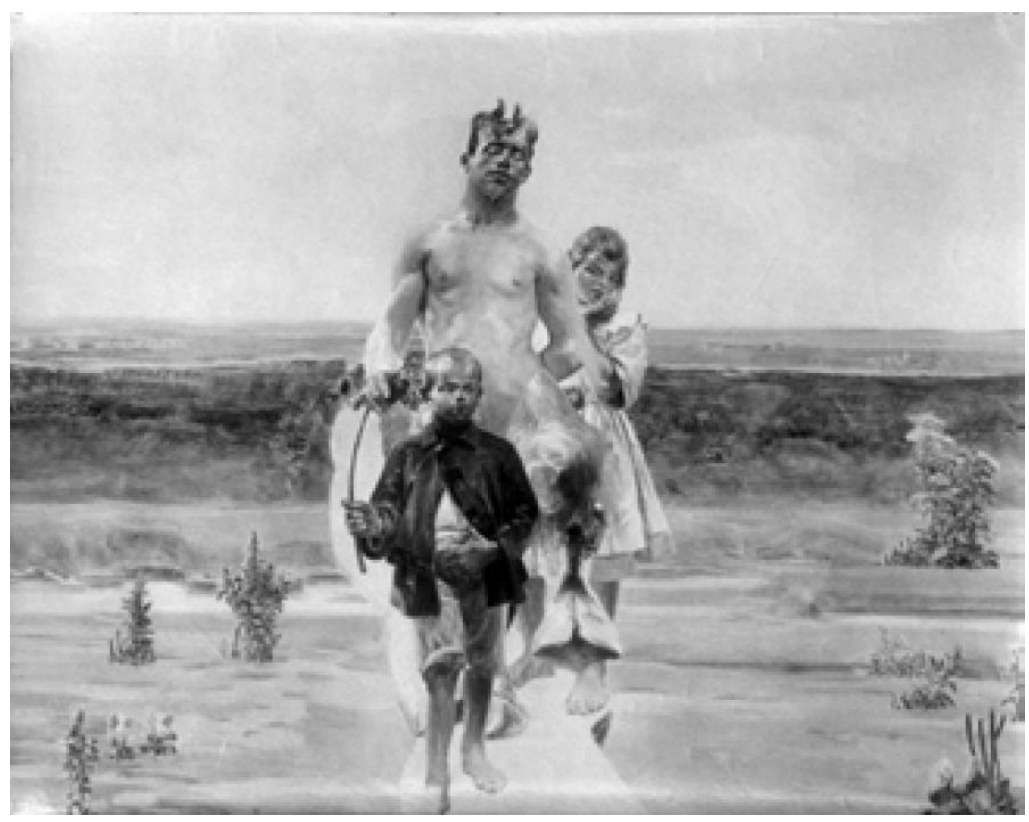

13. Jacek Malczewski, Der Blinde Faun [1910], Künstlerhaus Archive

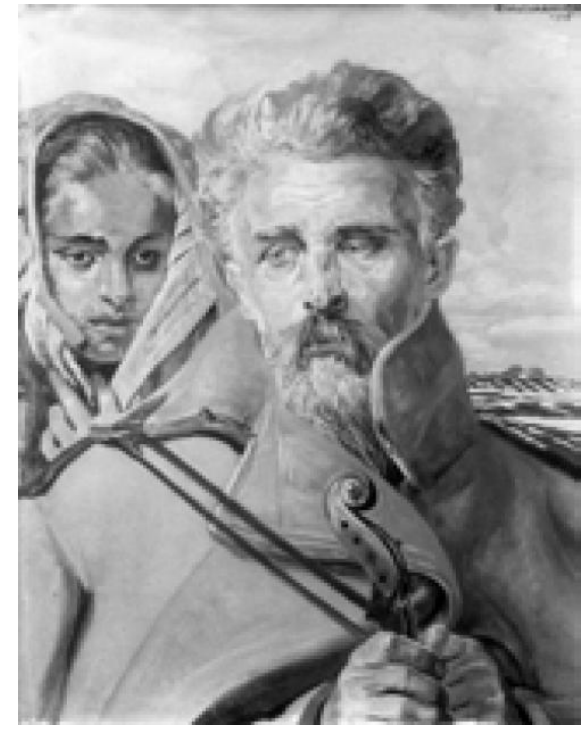

14. Jacek Malczewski, Der Geiger [1905, unknown variant of the portrait of Stanisław Wójcicki], Künstlerhaus Archive 


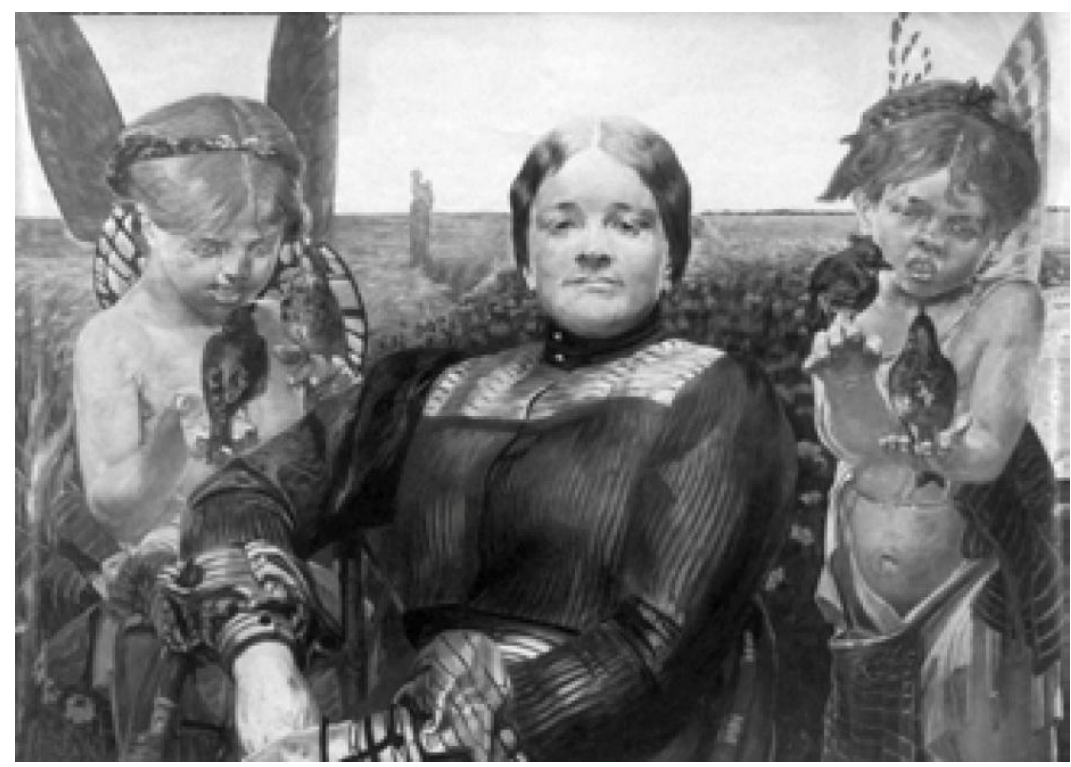

15. Jacek Malczewski, Die Schwester des Künstlers [n.d., Helena], Künstlerhaus Archive

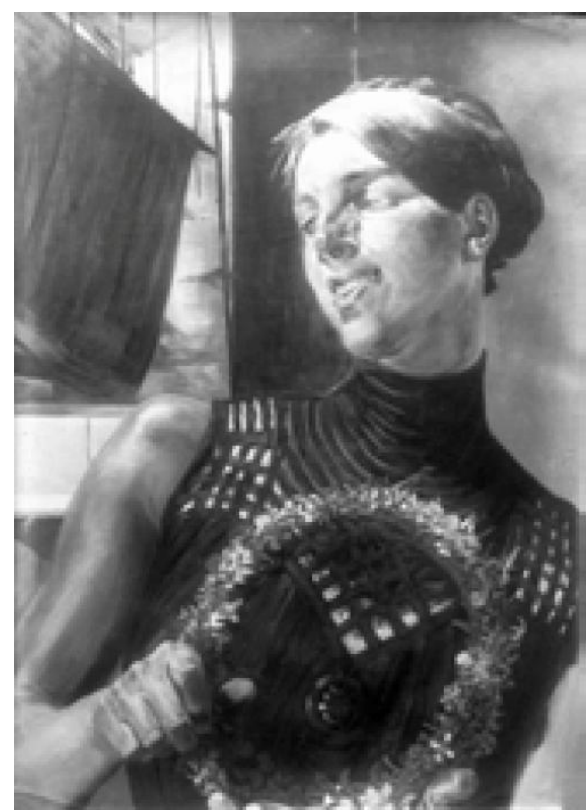

16. Jacek Malczewski, Triptik—Gloria \& Art I [1911], part one of the triptych, Künstlerhaus Archive 


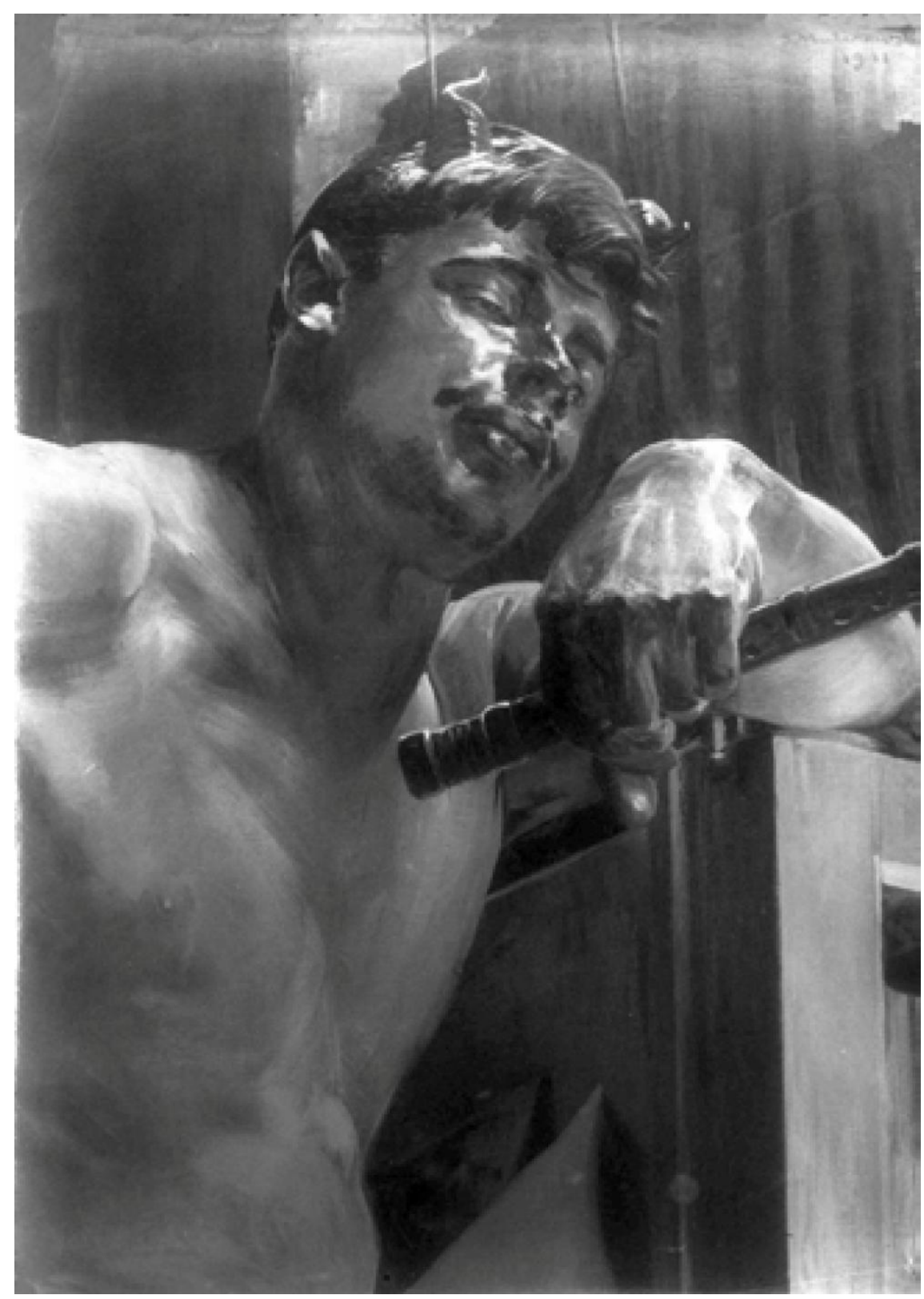

17. Jacek Malczewski, Triptik—Gloria \& Art III [1911], part three of the triptych, Künstlerhaus Archive 


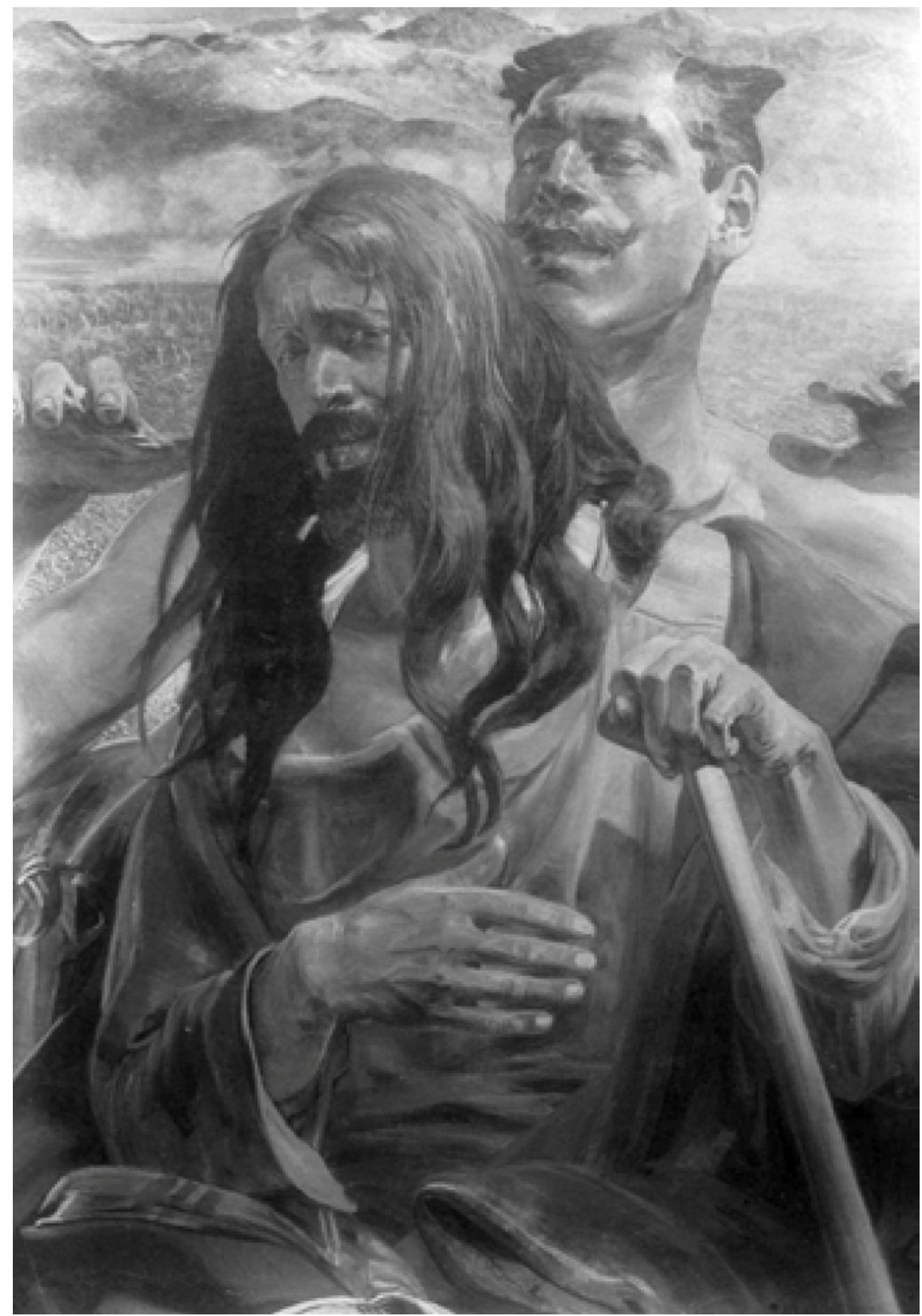

18. Jacek Malczewski, Die Versuchung Christi [1911], Künstlerhaus Archive 


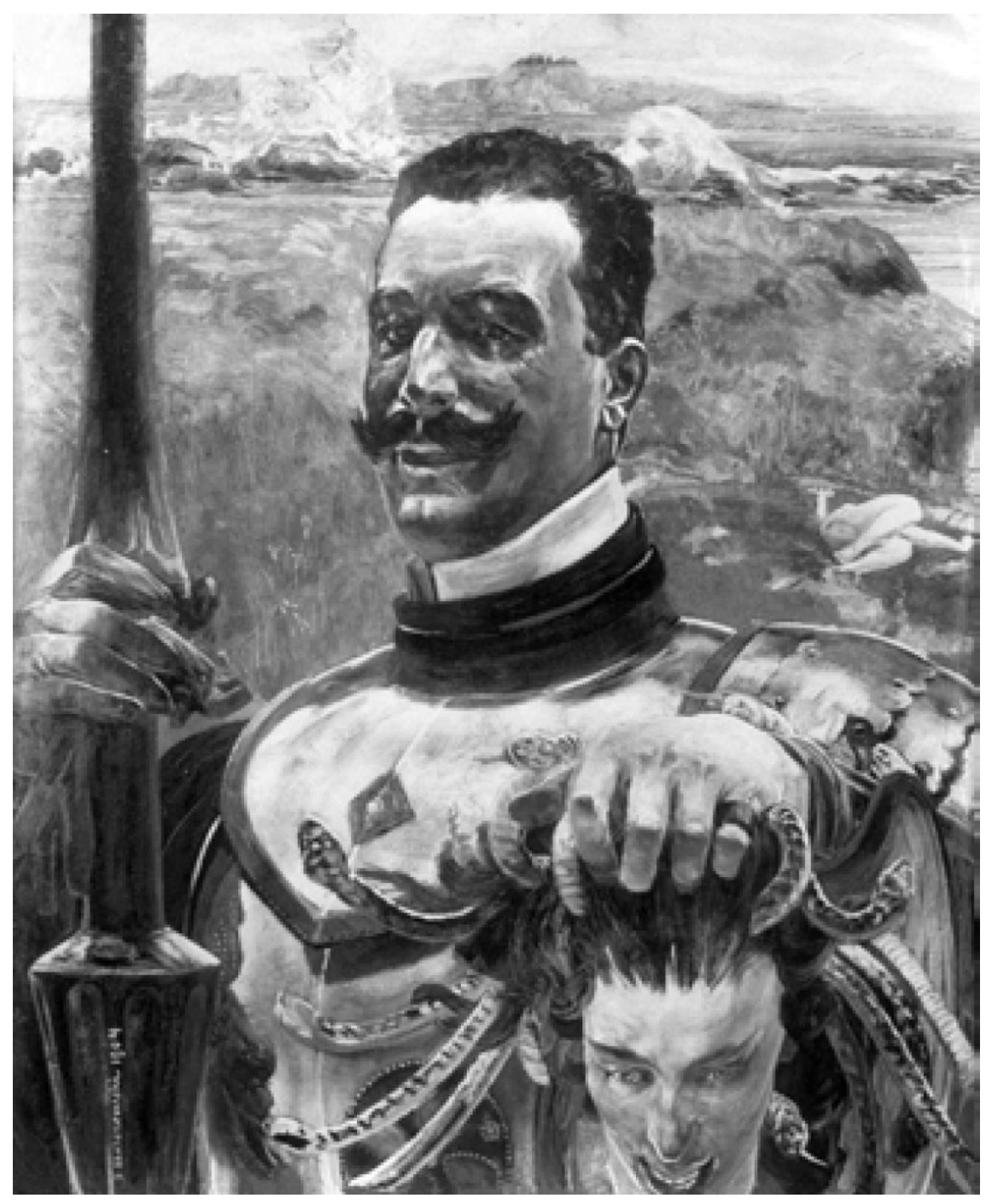

19. Jacek Malczewski, Persons 1 [1904], Künstlerhaus Archive 


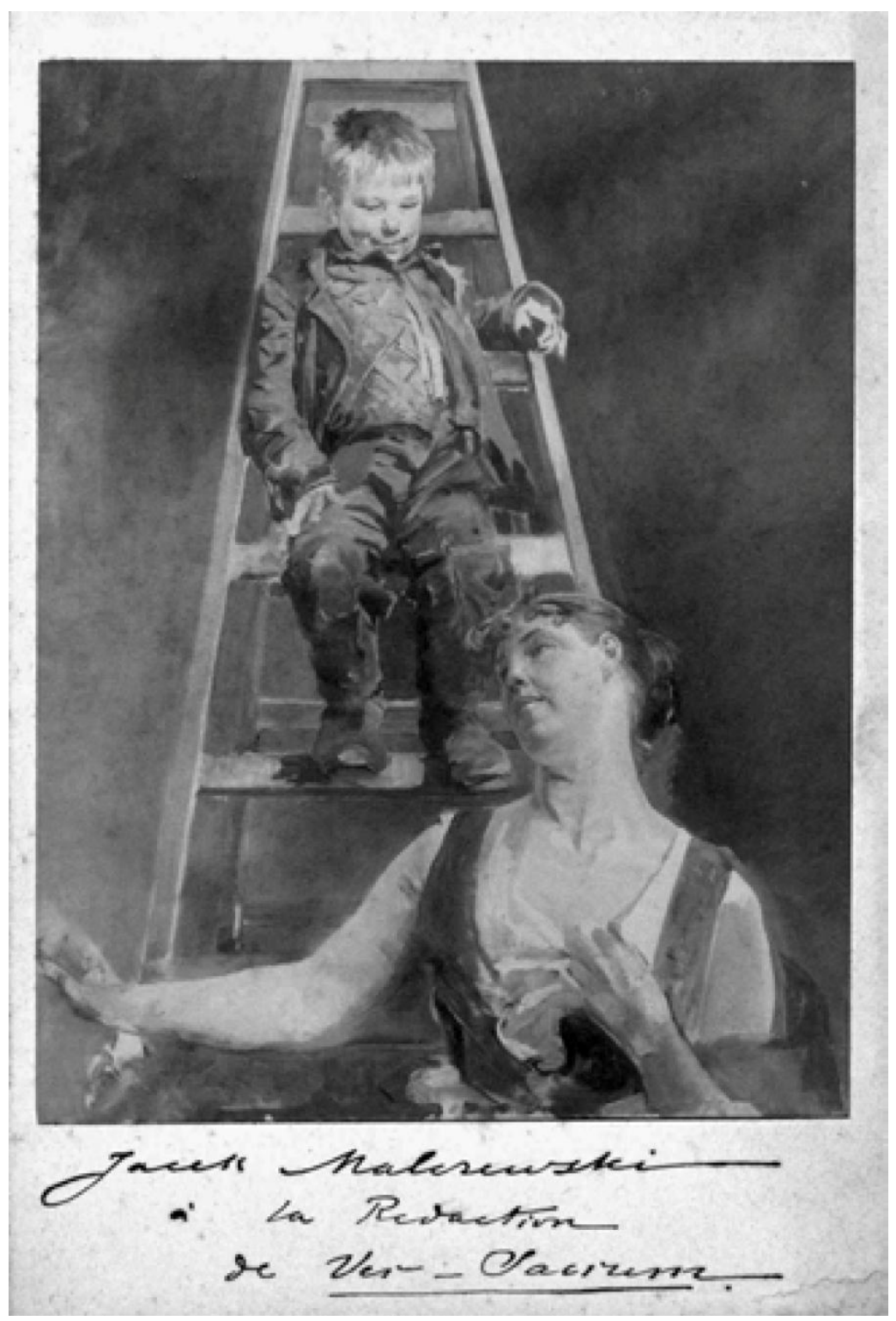

20. Jacek Malczewski, Carte de Visite [n.d.], Künstlerhaus Archive 


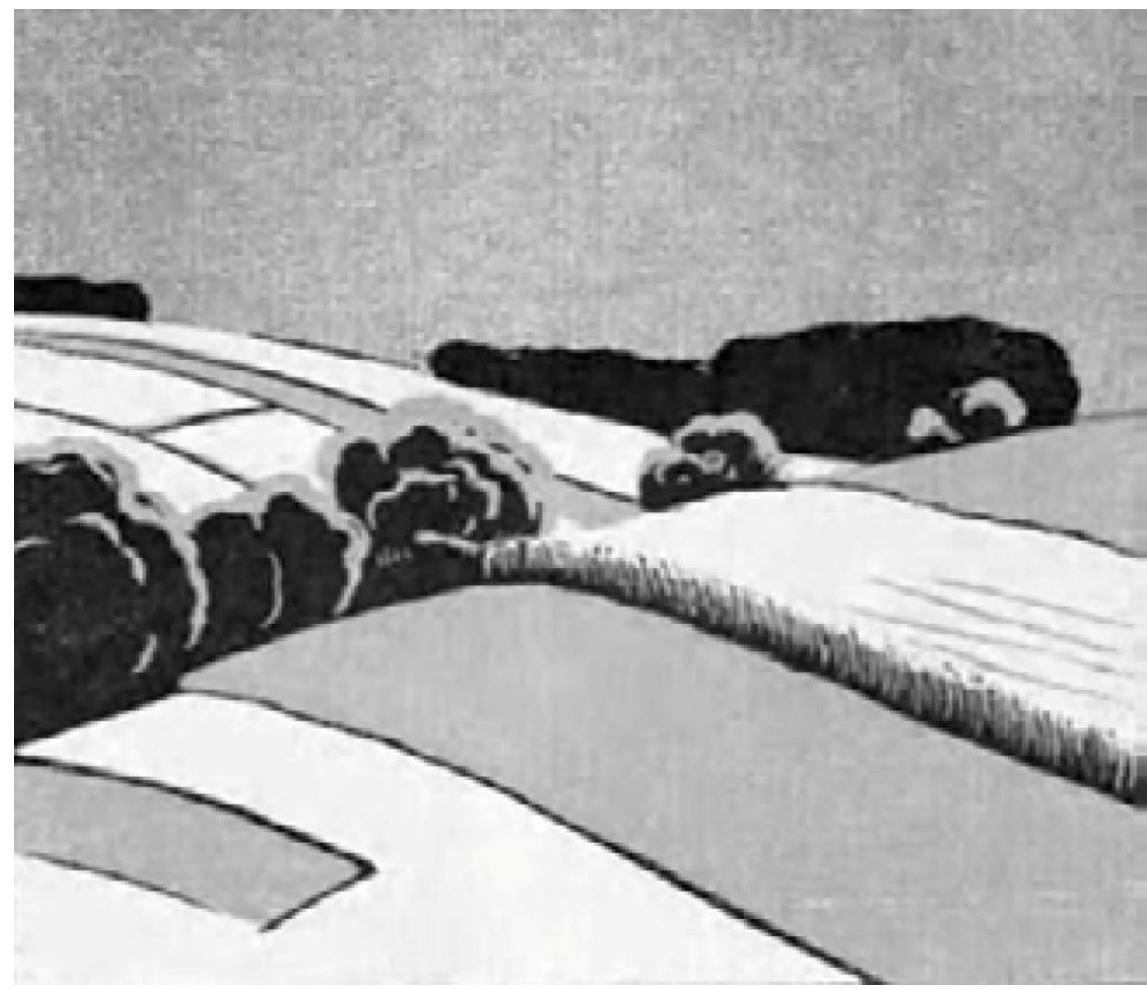

21. Hugo Henneberg, “Graphik,” Ver Sacrum 6 (1903), H.1: 353, by courtesy of: Bibliothek Österreichische Galerie Belvedere, Digital Library: https://www.belvedere.at/jart/prj3/belvedere/data// documents/dokumente/downloads/digitale-bibliothek/ver-sacrum/1903_versacrum_v06_72dpi.pdf 